\title{
ARASTTIRMA RESEARCH
}

\section{Korumacı ve Düşmanca Cinsiyetçiliğin Kadınların Sözel ve Sayısal Performansı Üzerindeki Etkileri \\ Effects of Benevolent and Hostile Sexism on Women's Verbal and Quantitative Performance}

\author{
Deniz Eniç 1 iD, Leman Pınar Tosun 2 (iD
}

\begin{abstract}
Öz
Çalışmada amaç, kadınlarıı bilișsel performansları (BP) üzerinde korumacı ve düșmanca cinsiyetçiliğin (KC, DC) etkilerini ve bu etkide rol oynayan değişkenleri incelemektir. $K C$ ve $D C^{\prime} y e$ maruz kalmanın $B P^{\prime} y e$ etkisine dair üç farklı görüşsten ikisinde (kalıpyarglların aktivasyonu ve istenmeyen düşünceler görüşleri), $\mathrm{KC}^{\prime} \mathrm{ye}$ maruz kalmanın $\mathrm{BP}^{\prime}$ 'de düşüşe yol açacă̆ı öngörülür ancak bunun nedeni olarak öne sürdükleri açıllamalar açısından bu görüşler birbirinden ayrllı. Öfke temelli tepki görüşünde ise $D C$ 'ye maruz kalmanın BP'yi yükselteceği öngörülür. İki deneyi içeren mevcut çalışmanın temel amacı, Türkiye bağlamında bu üç görüşten hangisinin geçerli olduğunu sinamaktır. Birinci deneye 80, ikinci deneye 159 kadın katilımcı dâhil oldu. Bu deneylerde katllımclar KC, DC ve Kontrol koşullarından birine atandı ve $B P$, sözel ve sayısal testleriyle ölçüldü. Illk çalışmada, deney gruplarının sayısal performansıını birbirinden farkllış̧madığı görülürken, DC koşulundakilerin sözel puanııı KC koşulundakilerden yüksek olduğu bulundu. Cinsiyetçiliğe maruz kalmanın sözel puanla ilişkisinde cinsiyetle özdeşleşme ve benlik saygısı değişkenlerinin düzenleyici rolü sınandı ancak anlamlı olmadığı anlaşıldı. DC'nin bilişsel performansı artıracağına dair öngörü sadece öfke-temelli tepki görüşünde var olduğundan, bu görüş 2 . deneyde daha detaylı incelendi. İkinci çalş̧ma bulgularında, deney gruplarııın sayısal performansının birbirinden farklılaşmadığı, fakat DC koşulunda yer alan katılımcıların sözel performansııın diğer iki koşula kıyasla daha yüksek olduğu ve öfke duygusunun bu ilişkiye araclılı ettiği görüldü. Özetle, mevcut çalısmadan elde edilen bulgular üç görüş arasından öfke temelli tepki görüşünü destekledi ve cinsiyetçiliğin bilişsel performansa etkisinin performans alanına bağıl olduğunu ortaya koydu.
\end{abstract}

Anahtar sözcükler: Düşmanca cinsiyetçilik, korumacı cinsiyetçilik, sözel performans, sayısal performans, öfke

\section{Abstract}

The aim of this study is to examine the effects of benevolent and hostile sexism (BS, HS) on women's cognitive performance (CP) and the variables playing role in these effects. Two of the three views about the impacts of BS and HS on CP (activation of stereotypes, mental intrusions) predict that exposure to BS would lead to decrease in (P, but they rationalized it differently. Anger-based reaction view predicted that exposure to $\mathrm{HS}$ would increase in CP. The main purpose of this study including two experiments is to test which of these three views is valid in Turkey. 80 women participated in the Experiment\#1, 159 women in the Experiment\#2. Participants were assigned to one of the BS, $\mathrm{HS}$ and Control Conditions in these experiments and verbal and quantitative tests were used for measuring CP. In the Experiment\#1, quantitative performance of groups didn't differ from each other, while verbal scores of women confronting with $\mathrm{HS}$ were higher than those in the BS condition. The moderator role of gender identification and self-esteem in the relationship between sexism and verbal score was tested and found to be non-significant. As the anger-based reaction view was the only one predicting higher $\mathrm{CP}$ in $\mathrm{HS}$ condition, this view was examined in Experiment\#2 in detail. In the Experiment\#2, the quantitative performance of the groups didn't differ, but the verbal performance of women in the $\mathrm{HS}$ condition was higher than the performance of women in the other conditions, and anger was mediated in this relationship. Shortly, findings support the anger-based reaction view and reveal that the effects of sexism on $C P$ depends performance domain.

Keywords: Hostile sexism, benevolent sexism, verbal performance, quantitative performance, anger

${ }^{1}$ Adana Alparslan Türkeş Bilim ve Teknoloji Üniversitesi, Adana

${ }^{2}$ Uludağ Üniversitesi, Bursa

$\triangle$ Deniz Eniç, Adana Alparslan Türkeş Bilim ve Teknoloji Üniversitesi, Psikoloji Bölümü, Adana, Turkey

denic@atu.edu.tr|0000-0002-5737-9520

Geliş tarihi/Received: 22.02.2021 | Kabul tarihi/Accepted: 30.08.2021 |Çevrimiçi yayı/Published online: 26.09.2021 
GÜNLÜK yaşam içerisinde cinsiyetçilik, hem açık ve kaba biçimleriyle hem de örtük ve sinsi biçimleriyle sürüp gitmektedir ve bu her iki tür cinsiyetçiliğe maruz kalmanın kadınları -sağlık durumlarından, bilişsel performanslarına kadar- pek çok açıdan olumsuz yönde etkilediği çeşitli çalışmalarla gösterilmiştir (Dardanne ve ark. 2007, Burgess 2013). Glick ve Fiske (1996), geliştirdikleri Çelişik Duygulu Cinsiyetçilik Kuramında cinsiyetçiliğin iki farklı biçimini tanıtarak, bu iki cinsiyetçiliğin hangi psikolojik süreçlerle kadınları etkilediğine dair açıklamalar sunmuştur. Mevcut çalışma, Glick ve Fiske'nin kavramsallaştırdığı iki farklı türdeki cinsiyetçiliğe maruz kalmanın kadınların sözel ve sayısal akademik performanslarına etkilerinin sorgulandığı iki deneyi içermektedir.

Çelişik Duygulu Cinsiyetçilik Kuramına göre (Glick ve Fiske 1996), klasik önyarg1 ve ayrımcılık tanımları cinsiyetçiliği açıklamada yetersiz kalır; zira ayrımcılık deneyimleri genel olarak, tek taraflı biçimde biri diğerine bağımlı olan gruplar arasında kendini gösterirken; cinsiyetçilik deneyimleri birçok açıdan birbirine karşılıklı bağımlı bulunan kadın ve erkek grupları arasında ortaya çıkar. Kadın ve erkeğin cinsellik ve üreme noktasında birbirine karşılıklı bağımlılı̆̆ı, bu grupların birbirine olumlu duygular beslemelerini bir zorunluluk haline getirir. Dolayısıyla, kuramda olumsuz tonda tek bir cinsiyetçilik tanımı yerine, hem olumlu hem de olumsuz içerikte birbirini tamamlayan iki farklı cinsiyetçilik türü olduğu ileri sürülür. Klasik cinsiyetçilik açıklamalarına denk gelen düşmanca cinsiyetçilik (DC), kadınların değersiz olduğuna ilişkin olumsuz ve katı tutumları kapsar. Sosyal, ekonomik ve siyasi konularda erkeklerin kadınlardan daha güçlü olduğunu belirten tutum ve davranışlar da DC kapsamındadır. Cinsiyetçiliğin diğer formu olan korumacı cinsiyetçilik (KC) ise kadınların saf, sevilmeye ve korunmaya değer cinsiyet grubu olduğu yönündeki inançları ve bu inançlardan hareketle sergilenen davranışları içerir. KC'nin ifadesindeki olumlu tonlamalar kimi zaman kadınların lehine gibi gözükse de altta yatan temel varsayım, kadınların erkeklere kıyasla zayıf ve yetersiz olduğudur. Cinsiyetçiliğin her iki formu da kadınların aleyhine olmakla birlikte, bu iki cinsiyetçilik türü arasında önemli farklılıklar söz konusudur. En belirgin farklılık iki cinsiyetçilik türünün ifade yolunda gözlenir. DC oldukça açık bir şekilde sergilenirken; KC örtük ve hatta olumlu bir dil üzerinden aktarılır (Connelly ve Heesacker 2012).

Alanyazına bakıldığında, KC ve DC ögelerine maruz kalan kadınların, bu cinsiyetçi ögelerden nasıl etkilendiğini ve bu ögeleri nasıl karşıladığını inceleyen araştırmalara rastlanmaktadır. Bu konuda yürütülen bir araştırmada, hem DC hem de $\mathrm{KC}$ tutumları ile karşılaşmanın kadınlarda alkol tüketimini yordadığı anlaşılmıştır (Hamilton ve DeHart 2020). Öte yandan, DC ve KC tutumlarının kadınlar üzerindeki etkilerinin birbirinden farklı olduğunu ortaya koyan çalışmalar da mevcuttur. $\mathrm{Bu}$ araştırmalarda DC tutumlarının, olumsuz ve sert tepkilere yol açtığı; KC tutumlarına gösterilen olumsuz tepkilerin ise daha az olduğu (Dardenne ve ark. 2007); hatta KC tutumlarının kimi zaman hedef alınan birey ve hatta toplum tarafından kabul edildiği görülmektedir (Glick ve Fiske 1996, Glick ve ark. 2000). KC'nin olumlu bir dil üzerinden ifade edilmesi, kadınlara kısa vadede birtakım kazanımlar sağlıyor gibi görünmesi ve genel cinsiyetçilik prototipinden sapması, bu tutumların cinsiyetçilik olarak alg1lanmasını engellemektedir (Barreto ve Ellemers 2005). Becker ve Wright (2011) ise çalışmalarında çelişik duygulu cinsiyetçiliğe maruz kalma ve kolektif eylem yönelimi arasındaki ilişkiyi incelemiş; sonuç olarak, KC'ye maruz kalan kadınların toplumsal cinsiyetle ilgili sistemi meşrulaştırma eğilimlerinin ve kadın olmanın avantajlarını algılama düzeylerinin arttığını ve dolaylı olarak, cinsiyet eşitsizliği karşısında kolektif eyleme katılımlarının azaldığını 
bulgulamışlardır. DC'ye maruz kalan kadınlarda ise sistemin adil olmadığı inancı artmakta, kadın olmanın kişisel avantajlarının algılanması azalmakta ve dolaylı olarak kolektif eyleme katılım yükselmektedir.

KC ve DC'ye maruz kalmanın kadınlar üzerindeki etkisinin incelendiği araştırmalardan bir diğerinde Dardenne ve arkadaşları (2007), bir iş başvurusu kurgusuna sahip deneysel çalışmalarında, kadın üniversite öğrencilerini üç koşuldan birine -KC, DC veya herhangi cinsiyetçilik ögesinin yer almadığ 1 kontrol koşuluna- rastgele atamış, atandıkları grubun hangisi olduğuna bağlı olarak kadınların önce bazı cinsiyetçi ifadelere maruz kalmasını/kalmamasını sağlamış, ardından her üç gruptaki kadınlara iş başvurusu senaryosunun bir parçası olarak bilişsel performans (BP) testi uygulayıp başarılarını karşılaştırmışlardır. Araştırmacılar bu çalışmada, KC ve DC'ye maruz kalmanın kadınların BP düzeyini nasıl etkileyebileceğine ilişkin şu üç farklı görüşten hangisinin geçerli olduğunu sınamışlardır:

1. Kalıpyargıların aktivasyonu görüşü: Bu yaklaşıma göre, belirli bir sosyal grupla ilgili kalıpyargıları etkin hale getirmek, söz konusu grubun üyelerinin bu yapıları doğrulayacak şekilde davranmalarına yol açmaktadır. Dolayısıyla, birbirinden farklı kalıpyargıları harekete geçiren $\mathrm{KC}$ ve DC ifadelerinin BP üzerindeki etkisi farklılaşacaktır. Şöyle ki, cinsiyet grubunun yetersizliğini örtük bir şekilde belirten $\mathrm{KC}$ ifadelerine maruz kalan bir kadında yetersizliğe ilişkin kalıpyargılar aktif hale gelecek, kişi bu kalıpyargılarla uyumlu davranacak ve sonuç olarak BP düzeyinde düşüş gözlenecektir. Öte yandan, kadınların zayıf olmasından ziyade erkekler tarafından acınası ve değersiz değerlendirildiklerine yönelik inançlarla ilişkili olan DC, kadın grubunun yetersizliği ile ilgili kalıpyargıları etkinleştirmeyecek; bu sebeple DC tutumlarının kadınların BP düzeyini azaltıcı bir etkisi gözlenmeyecektir.

2. Öfke temelli tepki görüşü: Bu yaklaşıma göre, DC'nin açık doğası kadınların karşılaştıkları durum karşısında öfke deneyimlemelerine, karşılaştıkları bu cinsiyetçi yaklaşımı haksız çıkarma arzusu duymalarına, herhangi bir bilişsel testte erkekler kadar veya erkeklerden üstün performans sergileme motivasyonlarının açığa çıkmasına ve dolayısıyla BP düzeylerinin artmasına neden olacaktır. Öte yandan, KC'ye maruz kalan kadınların öfke duyguları, motivasyonları ve BP düzeyleri üzerinde böylesi etkiler ortaya çıkması beklenmemektedir.

3. İstenmeyen düşünceler görüşü: Bu yaklaşımda, tıpkı kalıpyargıların aktivasyonu görüşündeki gibi, DC'ye değil KC'ye maruz kalmanın kadınların BP düzeyini düşürmesi beklenir. Bu görüşe göre, DC'ye kıyasla daha sinsi bir şekilde ortaya çıkan KC, kadınlarda olumsuz duygu ve düşüncelerin açı̆̆a çıkmasına neden olacaktır. Kadınlarsa bu olumsuzluğu karşı tarafın cinsiyetçiliğine atfetmeyecek; çünkü cinsiyetçiliğe maruz kaldıklarını fark etmeyeceklerdir. Sonuç olarak, test esnasında bilişsel kapasitelerinin büyük kısmını yetersiz, zayıf, başarısız olduklarına dair nereden geldiğini bilemedikleri istenmeyen düşüncelerle baş etmeye yönelten kadınların testteki performansı düşecektir. Öte yandan, DC'ye maruz kaldıklarında ortaya çıkan olumsuz düşünce ve duyguları kolaylıkla karşı tarafın cinsiyetçiliğine atfedebileceklerinden, kadınların BP düzeyi bu tutumlardan etkilenmeyecektir. 
Dardenne ve arkadaşlarının (2007) çalışmasının sonuçları, KC'nin kadınların bilişsel performansını DC'den daha olumsuz etkilediğini göstermiştir. Dahası, KC tutumlarıyla karşı karşıya kalan kadınların, DC tutumlarıyla karşılaşan ve herhangi cinsiyetçi tutumla karşılaşmayan kontrol grubundakilere kıyasla performansları esnasında endişe etme, kendinden şüphe etme ve kendine güvenmeme tepkilerini daha fazla gösterdikleri bulunmuştur. Yukarıdaki görüşlerden üçüncüsünü destekleyecek şekilde, KC ve BP arasındaki bu ilişkiye, kadınların maruz kaldıkları istenmeyen düşüncelerin aracılık ettiği görülmüştür. Aynı deneysel modelin kullanıldığı bir başka çalışmada Dumont ve arkadaşları (2010), yine istenmeyen düşünceler yaklaşımını destekler nitelikte bulgular ortaya koymuştur.

Mevcut araştırma, KC ve DC'ye maruz kalmanın kadınların iki farklı alandaki (sözel ve sayısal) performansına etkilerini ortaya çıkarmak amacıyla gerçekleştirilmiştir. Türkiye'den veri toplanan bu çalışmada cinsiyetçiliğin BP üzerindeki etkisinde Dardenne ve arkadaşlarının (2007) ifade ettiği görüşlerden hangisinin geçerli olduğu incelenmiştir. İnsanların davranışları, üyesi oldukları toplum içerisinde şekillenir ve bir toplumun kültürel yapısı, o toplumdaki insanların nasıl düşündükleri, hissettikleri ve davrandıkları üzerinde etkilidir. Dolayısıyla, KC ve DC'ye maruz kalmanın kadınların bilişsel performansına etkilerine dair ileri sürülen görüşler arasından "istenmeyen düşünceler" yaklaşımının geçerliliğgi Belçika'da gerçekleştirilen çalışmalarda ortaya konmasına rağmen, durumun Türkiye gibi Batı ülkeleri dışındaki bir kültürde nasıl olduğunun incelenmesi önemlidir. Türkiye, kadın ve erkek olmanın anlamının oldukça sıkı bir şekilde cinsiyet rolleri üzerinden belirlendiği geleneksel bir toplumdur (Sakallı-Uğurlu 2010). Cinsiyetler arasındaki hiyerarşik yapılanma ve cinsiyet eşitsizliği bakımından Türkiye ve Belçika arasında önemli farklılıklar söz konusudur. Ekonomik ve politik anlamda cinsiyetler arasındaki eşitsizlik, KC ve DC düzeyleri Türkiye'ye kıyasla Belçika'da daha düşüktür (Glick ve ark. 2000). Ayrıca, kadınların ekonomiye katılımı, fırsat eşitliği, eğitim imkânları ve siyasi konumları gibi kriterlere bakılarak Dünya Ekonomik Forumu tarafından 2018 yılında yayınlanan cinsiyet eşitliğine dair raporda, Belçika 149 ülke arasından 32. sırada bulunurken, Türkiye'nin 130. sırada yer aldı̆̆ görülmüştür (World Economic Forum 2018). Dolayısıyla, mevcut araştırma ile daha önce Avrupa toplumundan gelen verilerde gözlenen KC ve DC'nin kadınların bilişsel performansına etkilerinin, geleneksel cinsiyet rollerinin Avrupa'dan çok daha katı ve cinsiyetler arası eşitsizliğin daha yüksek olduğu Türkiye toplumunda geçerli olup olmadığının sınanması değerlidir. Ayrıca, Türkiye'de yapılan araştırmalarda KC ve DC olguları genellikle anket çalışmaları yoluyla kalıcı birer bireysel özellik olarak ele alınmış (Örn. Sakall1-Uğurlu ve Glick, 2003, Sakall1-Uğurlu ve Ulu 2003) ve bu bileşenlerin çeşitli değişkenlerle ilişkileri sorgulanmış; fakat alanyazın incelemesi sırasında kadınların KC ve DC'ye maruz bırakılıp etkilerinin gözlendiği deneysel araştırmalara rastlanmamıştır. Türkiye örnekleminde bu türde bir deneysel çalışma ile alanyazındaki eksikliğin giderilmesine katkı sağlanacaktır.

Mevcut araştırma kapsamında Dardenne ve arkadaşlarının (2007) geliştirdiği deney yönteminin kullanıldığı iki çalışma yürütülmüştür. Katılımcılara bir iş başvurusu senaryosunun parçası olarak bilişsel performans testleri uygulanmıştır. Ancak Dardanne ve arkadaşlarının (2007) çalışmasından farklı olarak, BP ölçümü için sözel ve sayısal ALES sınav soruları kullanılmıştır. Üniversite mezunlarının pek çoğu ALES puanı ile işe yerleştirilecekleri devlet kadrolarına başvurduğundan, araştırmada işe başvuran rolüne girmeleri istenen katılımcılara ALES soruları sunulmasının çalışmanın inandırıcılığını 
artırıp ekolojik geçerliliğine katkı sağlayacağı düşünülmüştür. Aynı zamanda, KC ve DC'nin BP üzerindeki etkisinin tek bir test üzerinden değil; sözel ve sayısal olmak üzere iki ayrı alandaki performans testi üzerinden incelenmesi, cinsiyetçiliğin performansa etkilerinin performans alanına göre değişeceği yönünde bir hipotezin test edilmesini mümkün kılmaktadır. Kadın ve erkeklerin sözel ve sayısal alandaki yetkinlik düzeylerine ilişkin oldukça yaygın kabul gören olgusal kalıpyargılar ("kadınlar sözel alanda erkeklerden daha başarılıdır" ve "erkekler sayısal alanda kadınlardan daha başarılıdır”) mevcuttur (Brannon 2010). Sosyal gruplara ilişkin kalıpyargıların, grup üyelerinin ilgili alandaki performansını etkilediği önceki araştırmalarda gösterilmiştir (Örn. Schmader ve Johns 2003). Kadınların sayısal ve sözel performans alanlarındaki yetkinliklerine ilişkin kalıpyargıların farklı olduğu bilgisinden hareketle, mevcut çalışmada KC ve DC'nin bu alanlar üzerindeki etkilerinin birbirinden farklı olabileceği iddiası test edilecektir. Dardenne ve arkadaşlarının (2007) geliştirdiği görüşlerden yola çıkarak, sözel ve sayısal alanlarda her bir yaklaşımın öngöreceği sonuçlar aşağıdaki şekilde düzenlenmiştir:

1. Kalıpyargıların aktivasyonu görüşü: $\mathrm{Bu}$ yaklaşıma göre cinsiyetçilikle karşılaşmanın kadınların BP düzeyini düşürme nedeni, olumsuz kalıpyargıları harekete geçirmesidir. Bu kalıpyarg1 aktivasyonu DC'ye maruz kalmakla değil KC'ye maruz kalmakla ortaya çıkar; çünkü korumacı tutumların örtük bir şekilde ifade edilmesi, durumun karşı tarafın cinsiyetçiliğine atfedilmesini zorlaştırmaktadır. Yukarıda ifade edildiği gibi genel olarak kadınların sayısal alandaki becerileri azımsanırken, sözel alanda kadınlar erkeklerden daha becerikli kabul edilmektedir. Eğer kalıpyargı aktivasyonu görüşü geçerli ise, kadınların KC'ye maruz kalmalarının onların sayısal alandaki performanslarını olumsuz etkilemesi fakat sözel performanslarında böylesi bir etkinin ortaya çıkmaması beklenir.

2. Öfke temelli tepki görüşü: $\mathrm{Bu}$ görüşe göre $\mathrm{DC}$ tutumlarıyla karşılaşmak kadınları öfkelendirir ve başarı motivasyonlarını artırır. DC'nin sözel ve sayısal performans üzerindeki etkilerinin birbirinden farklılaşması beklenmektedir. Alanlar arasında performans farklılı̆̆ı beklenmesinin en önemli nedeni, sözel ve sayısal becerilerde cinsiyetlere yöneltilen kalıpyargıların olmasıdır. Öncelikle, araştırmaya katılan kadınlar -cinsiyet gruplarının sözel alandaki yeterliliğine dair olumlu ve sayısal alandaki yeterliliğine dair olumsuz inançların yaygın olması nedeniyle- genel test performanslarını arttırmak için sözel sorular üzerinde gösterecekleri ekstra gayretin sayısal alanda gösterecekleri çabadan daha çok işe yarayacağına inanabilirler. Dolayısıyla, testte ortaya koyacakları genel başarıyı arttırmak için bilgi ve becerilerinin zayıf olduğunu düşündükleri sayısal alana değil, kendilerine güvenlerinin tam olduğu sözel alana yatırım yapabilirler. Bunlardan hareketle, düşmanca cinsiyetçiliğe maruz kalmanın yaratacağı öfkenin yalnızca sözel testteki performansı artıracağı beklenmektedir.

3. İstenmeyen düşünceler görüşü: $\mathrm{Bu}$ görüşe göre, $\mathrm{KC}$ tutumlarıyla karşılaşmanın kadınların hem sözel hem de sayısal performanslarını olumsuz etkilemesi beklenir. KC ile karşılaşan kadınlarda neye atfedeceklerini bilemedikleri bir yetersizlik hissi ve kendinden şüphe etme düşüncesinin yoğunlaşması sonucunda, sözel ve sayısal testlerin her ikisinde de performans düşüşü görülecektir. 
Mevcut çalışmada, yukarıdaki görüşlerin geçerliliğini incelemek üzere iki deney yürütülmüş; bu deneylerde, cinsiyetçiliğe maruz kalma ve performans arasındaki ilişkide rol oynayabileceği öngörülen çeşitli aracı ve düzenleyici süreçlerin etkileri incelenmiştir. Önceki araştırmaların bulguları, cinsiyetçilik deneyimlerinin tüm kadınları benzer şekilde etkilemediğine; kadınların karşılaştıkları cinsiyetçi olaylar karşısında gösterdikleri tepkinin, benlik saygısı ve cinsiyetle özdeşleşme düzeylerine bağlı olduğuna işaret etmektedir (Örn. Moradi ve Subich 2004, Dardenne ve ark. 2007). Benlik saygisı ve cinsiyetle özdeşleşme düzeyi kişiler arası farklılık gösteren bireysel özelliklerdir. Bu kişisel özellikler, bireylerin yüz yüze geldikleri cinsiyetçilik deneyimleri karşısında nasıl tepki vereceklerini belirleyen önemli etmenlerdendir. Örneğin, yüksek benlik saygisı, cinsiyetçilik deneyimleri karşısında kadınları koruyucu bir işleve sahiptir. Şöyle ki, algılanan cinsiyet eşitsizliği ve depresyon arasındaki ilişki, benlik saygısı düşük kadınlarda benlik saygısı yüksek olanlara kıyasla daha güçlüdür (Corning 2002). Benzer şekilde, algılanan cinsiyet ayrımcılığı ve stres arasındaki ilişki de kadınların benlik saygısı düzeyine göre değişmektedir (Moradi ve Subich 2004). Söz konusu ilişki benlik saygısı düşük kadınlar için anlamlı ve pozitif iken; aynı ilişki benlik saygısı yüksek kadınlar için anlamlı değildir. Yani, kendini daha az değerli gören kadınlar, cinsiyetçiliğe maruz kalma gibi olumsuz bir durumla baş etmede zorlanıp bu olumsuzluktan daha fazla etkilenmektedir (Moradi ve Subich 2004).

Grupla özdeşleşme düzeyi -benlik saygısı gibi- bireyin grup üyeliği hakkında maruz kaldığı ayrımcılık deneyimlerine nasıl tepki vereceğini şekillendiren bireysel özelliklerden biridir. Cinsiyetçilikle karşılaşan kadınlarda depresyon ve benlik saygısı düzeyleri arasındaki ilişkinin incelendiği bir araştırmada, cinsiyetle özdeşleşme düzeyinin bu ilişkiyi etkileyen önemli bir faktör olduğu görülmüştür (McCoy ve Major 2003). Araştırmacıların cinsiyetçi olarak tanımladığı bir erkek tarafından olumsuz değerlendirilen kadınlardan cinsiyetle özdeşleşme düzeyi düşük olanların, cinsiyetle özdeşleşmesi yüksek olanlara göre depresif duyguları daha düşük düzeyde hissettikleri ve daha yüksek benlik saygısı rapor ettikleri bulunmuştur (McCoy ve Major 2003). Grupla özdeşleşme düzeyi, kadınların cinsiyetçilik deneyiminin ardından kalıpyargı tehdidine karşı ne ölçüde dayanıklılık göstereceğini de etkilemektedir. Örneğin, Schmader (2002) tarafından gerçekleştirilen bir çalışmada, cinsiyet özdeşleşmesi yüksek kadınlar matematik performanslarının erkeklerle kıyaslanacağı bilgisini aldıklarında, yani cinsiyet kimlikleri ön plana çıkarıldığında, erkeklerden daha düşük performans sergilemiştir. Cinsiyet kimliklerine bağl1lı̆̆ yüksek olmayan kadınlara bakıldığında ise cinsiyet kimliğinin belirginleştirilmesinin bu kadınların performansını azaltıcı bir etki yaratmadığ1 görülmüştür.

Cinsiyetle özdeşleme düzeyi yüksek olan kadınların cinsiyetçilik deneyimlerinden olumsuz etkilendiğini gösteren araştırmaların yanı sıra kadın grubuna güçlü bağlılığın cinsiyetçilik durumlarında bireylere dayanıklılık sağladığını gösteren bulgular da mevcuttur. Örneğin, Dardenne ve arkadaşları (2007), açık bir dille ifade edilen cinsiyetçilik deneyimi ile karşılaşan cinsiyet kimliği ile özdeşleşme düzeyi yüksek olan kadınların, özdeşleşme düzeyi düşük olanlara kıyasla BP düzeyini düşürücü olumsuz düşüncelere daha az kapıldıklarını ve daha yüksek BP sergilediklerini bulgulamıştır. Kadınların cinsiyet kimliği ile özdeşleşme düzeyi bir bakıma onları cinsiyetçilik karşısında koruyan bir faktör olarak işlev göstermiştir. Alanyazından gelen bu farklı yöndeki bulgular bir araya getirildiğinde, cinsiyetle özdeşleşme düzeyinin çelişik duygulu cinsiyetçiliğin iki formuna karşı kadınları duyarlı hale getiren bir özellik mi, yoksa onları 
cinsiyetçiliğin olumsuz etkilerinden koruyan bir etmen mi olduğunu incelemek gerektiği düşünülmektedir.

Yukarıda bahsedilen araştırma bulgularından hareketle mevcut araştırmayı oluşturan her iki deneyde de, kadınların cinsiyetçiliğe maruz kalmaları ile bilişsel performansları arasındaki ilişkide düzenleyici rol oynayabilecek birer etmen olarak cinsiyet kimliği ile özdeşleşme ve benlik saygısı düzeyi ele alınmıştır.

\section{Deney}

Araştırmanın birinci deneyinde temel amaç, $\mathrm{KC}$ ve $\mathrm{DC}$ 'nin $\mathrm{BP}$ üzerindeki etkilerini Dardenne ve arkadaşlarının (2007) çalışmasındaki deneysel modelin bir benzerini kullanarak yeniden test etmektir. Yukarıda da aktarıldığı gibi, Dardenne ve arkadaşları, yaptıkları deneysel çalışmaların nasıl sonuçlanabileceğine dair üç farklı yaklaşımın beklentilerini sunmuşlar; deneylerden elde edilen sonuçlar ise bu görüşlerden “istenmeyen düşünceler” yaklaşımının öngörülerini doğrulamıştır: KC'ye maruz kalmak, kadınların kendi performanslarına şüphe ve kaygıyla yaklaşmak gibi istenmeyen düşüncelerini artırarak BP düzeyleri üzerinde olumsuz etki yaratmıştır. Mevcut çalışmanın birinci deneyinde, Türkiye'de benzer koşullarla karşılaşan kadın katılımcıların cinsiyetçi ifadelere nasıl tepki verecekleri incelenmiştir. Dardanne ve arkadaşlarının çalışmasından farklı olarak, katılımcılara sözel ve sayısal olarak iki bölümden oluşan bir test sunulmuştur. $\mathrm{Bu}$ iki alanda kadın ve erkeklerin yeterliliğine dair kalıpyargısal inançların farklı olması ve bu farklılıktan ötürü cinsiyetçi ifadelerin performans üzerindeki etkisinin performans alanına göre değişmesi beklenmiştir.

\section{Deney}

Birinci deneyden elde edilen bulgular doğrultusunda ikinci deney tasarlanmıştır. Bu çalışma, ilk çalışmanın bulgularının başka bir örneklem grubunda geçerliliğinin incelenmesi ve ayrıca, KC ve DC'nin bilişsel performans üzerindeki etkisinde başta öfke duygusu olmak üzere çeşitli duyguların ve performans motivasyonunun aracı rolünün incelenmesi amacıyla tasarlanmıştır.

Cinsiyetçi olayların hedefinde bulunmak kadınların hem kişisel kimliğine, hem de sosyal kimliğine yöneltilen bir tehdit olduğundan, bu deneyimlerin kadınlarda çeşitli duygusal tepkilere yol açması kaçınılmazdır. Cinsiyetçilik alanyazınında, KC ve DC tutum ve davranışlarıyla karşılaşan kadınların gösterdiği duygusal tepkilerin birbirinden farklılaştığını gösteren çalışmalar mevcuttur (Örn. Barreto ve Ellemers 2005, Bosson ve ark. 2010). Öfke temelli tepki yaklaşımında ifade edildiği gibi bu iki cinsiyetçilik türü, maruz kalan kadınlarda ne düzeyde öfke yarattıkları açısından birbirinden farklıdır. DC'nin hedefi olan kadınlar, KC ile karşılaşan kadınlara göre daha fazla öfke deneyimlemektedir (Barreto ve Ellemers 2005).

Bireyin bir durumla karşılaştığında hangi duyguyu hissettiğgi, hem vereceği davranışsal tepkiyi hem de bilgi işlemleme sürecini etkiler (Schwarz 1990, Bodenhausen ve ark. 1994). Bilişsel Ayarlama Modeline göre, birey sıkıntılı bir durumla veya herhangi bir tehdit unsuru ile karşılaştığında olumsuz duygular hissederken; tehdit algılamadığı durumlarda veya pozitif olaylarla karşılaştığında olumlu duygular deneyimler. Hissedilen duygular ise içinde bulunulan durum ve çevrenin güvenliği ile ilgili önemli ipuçları sağlar. Duygular ve bilişsel süreçler arasında ilişki kuran model, çevrenin güvenli olduğuna işaret eden olumlu duygular deneyimlendiğinde, ekstra çaba sarf edilmeyerek kestirme düşünce 
tarzının kullanılacağını; işler bozulmaya başladığında ortaya çıkan olumsuz duyguların ise kişiyi, bilgiyi kapsamlı bilişsel işleme sürecinden geçireceği analitik düşünce tarzına yönlendireceğini ileri sürer (Schwarz 1990).

Birinci deneyden elde edilen bulgular ve öfke temelli tepki yaklaşımından hareketle, bu ikinci deneyde DC'nin sözel test performansını arttırması beklenmiştir. Ayrıca, Dardenne ve arkadaşlarının (2007) ileri sürdüğü öfke temelli tepki yaklaşımı, Bilişsel Ayarlama Modelinin sunduğu kuramsal bilgiler ve çelişik duygulu cinsiyetçiliğin yol açtığı duygulara ilişkin görgül çalışma bulguları bir araya getirildiğinde, maruz kalınan cinsiyetçilik türü ve sergilenen performans arasındaki ilişkide deneyimlenen duyguların (özellikle öfke duygusunun) aracılık edeceği öngörülmüş̧tür. Şöyle ki, DC ile karşılaşan kadınların öfke hissinde artış olacağı ve öfke duygusundaki bu değişimin katılımcıların gösterecekleri test performansını yükselteceği düşünülmüştür. $\mathrm{Bu}$ etkinin, sayısal testtense sözel testte kendini göstereceği beklentisi, farklı bölümlerde okuyan öğrenciler için test edilmiştir.

Brehm (1996, akt. Thacker 1992) tarafindan sunulan Tepkisellik Teorisine göre birey, içinde bulunduğu durumu ya da çevreden getirilen sınırlamaları adaletsizlik olarak değerlendirdiğinde tepkisellik denilen psikolojik bir süreç deneyimler. Hissedilen bu tepkisellik, kişinin adaletsizliği ortadan kaldırmak için motive olmasına ve daha fazla çaba sarf etmesine yol açar. Kadınları yalnızca cinsiyetleri nedeniyle adaletsiz tutum ve davranışların hedefi haline getirmek ise tepkisellik deneyimlemelerine neden olacaktır (Zawadzki ve ark. 2012). Dardenne ve arkadaşları (2007), tepkisellik hissinin artmasına yol açan cinsiyetçilik deneyimlerinin öfkeyi ve performansa ilişkin motivasyonu arttırabileceğini ifade eder. Önemli olan nokta ise $\mathrm{KC}$ ve DC'nin, öfke duygusunu ve performans motivasyonunu arttırma potansiyellerinin birbirinden farklı olmasıdır. Bu deneyde öfke temelli tepki görüşünden hareketle, düşmanca cinsiyetçiliğe maruz kalan kadınların deneyimledikleri öfke hissinde ve performansa ilişkin motivasyonlarında artış olacağı; öfkenin ve performansa ilişkin motivasyonun, cinsiyetçilik ve test performansı arasındaki ilişkiye aracılık edeceği öngörülmüştür.

\section{Yöntem}

\section{Örneklem}

Araştırmanın birinci deneyine yaşları 18-30 arasında değişen ve Bursa Uludăg Üniversitesi (B.U.Ü.) Sosyoloji Bölümünde öğrenim gören 80 kadın lisans öğrencisi katılmıştır (Ort. Yaş = 20.81, S = 2.22). 28 katılımcı KC koşulunda, 27 katılımcı DC koşulunda geri kalan 25 katılımcı ise kontrol koşulunda yer almıştır.

İkinci deneye B.U.Ü.'de öğrenim gören ve yaşları 18-39 arasında değişen 159 kadın lisans öğrencisi katılmıştır (Ort. Yaş = 20.59, S = 2.23). Çalı̧̧ma kapsamında Fen Edebiyat Fakültesi'nin Psikoloji, Türk Dili ve Edebiyat1, Tarih, Matematik ve Felsefe bölümlerinden dengeli bir şekilde veri toplanmaya çalışılmıştır (sırasıyla \% 18.2, \% 21.4, $\%$ 17.6, \% 18.9, \% 23.9). Test performanslarında katılımcıların bölümlerinden kaynaklı farklılıkların koşullara dengeli dağılmasını sağlayabilmek için, deney gruplarına için her bölümden birbirine yakın sayıda katılımcı atanmıştır. Kayıp veri nedeniyle üç katılımcının değerlendirme dışı bırakılması sonucunda analizlere dâhil edilen katılımcı sayısı 156'dır. 54 katılımcı KC koşuluna, 49 katılımcı DC koşuluna atanırken, kontrol grubunda yer alan katılımcı sayısı 53'tür. 
Araştırmada ulaşılacak örneklem büyüklüğü G Power 3.1 (Faul ve ark. 2007) güç analizi yöntemi kullanılarak hesaplanmıştır. Analiz sonucunda tek yönlü ANOVA için anlamlılık düzeyi $(\alpha)$ 0.05, istatistiksel güç $\% 80$ ve etki büyüklüğü .04 alındığında ulaşılması gereken örneklem büyüklüğü 66 olarak bulunmuştur. Bu nedenle, iki deneyde ulaşılan katılım sayısının çalı̧̧ma için uygun olduğu anlaşılmaktadır.

\section{Ölçekler}

\section{Deney}

\section{Cinsiyetçiliğin değişimlendiği açıklayıcı metin}

Katılımcılardan kendilerini çalışmanın birinci aşaması boyunca bir iş başvurusunda gibi hayal etmelerinin istendiği metin aracılığıyla cinsiyetçilik değişimlenmiş ve metinler üç deney grubunda yer alan katılımcılar için birbirinden farklılık göstermiştir. Cinsiyetçiliğin değişimlendiği metinler alanyazında bu konuda yapılmış çalışmalardan yola çıkarak hazırlanmıştır (Dardenne ve ark. 2007, Dumont ve ark. 2010). Kontrol koşulunda ilgili işin tanımı ve işe alınacak personelde aranan özelliklerin yer aldığı ifadeler kullanılmış ve herhangi bir cinsiyetçilik ögesine yer verilmemiştir (Örn. Şirketimiz bir kimyasal fabrikası olup; iş birliğine yatkın, iletişimi kuvvetli, müşterilerle ilgili ve müşterilerin ihtiyaçlarını önemseyen kadın iş arkadaşları aramaktadır). DC koşulunda, kadınların erkeklerden daha zayıf oldukları için çevresel etmenlerden kolaylıkla rahatsız oldukları ve karşılaştığı zorlukları abartma eğilimi gösterdikleri; ayrıca erkekler üzerinde güç elde etmek istedikleri yönündeki inançları hatırlatan ifadeler yer almıştır (Örn. İşe alacağımız kadınların, erkekler üzerinde güç ve kontrol elde etmek için iş hayatında karşılaştıkları sorunları abartmak eğiliminde olmamalarını umuyoruz). KC koşulunda, kadınların zayıf olduklarını ve erkeklerin yardımına ihtiyaç duyduklarını belirginleştiren cümlelere yer verilmiştir (Örn. Tüm erkek çalı̧sanlarımız yeni işe başlayacak kadınlara yardım etmenin öneminin farkındadır ve kadın arkadaşların yeni işlerine uyum sağlaması için gerekli yardımları yapacaklardır).

\section{Performans testi}

Sözel ve sayısal alandan onar sorunun yer aldığı performans testi maddeleri, YÖK tarafından uygulanan ALES'te 2006-2013 yılları arasında çıkmış sorulardan oluşmaktadır. Araştırmacılar tarafından seçilen 50 ALES sorusunun (25 sayısal, 25 sözel) B.U.Ü. Psikoloji Bölümünde öğrenim gören 60 kişilik bir öğrenci grubuna uygulandığ1 pilot çalışmanın ardından, orta zorluk seviyesinde 20 soruda karar kılınmıştır.

\section{Ara metin}

Performans testlerinin ardından katılımcılara sunulan metinde işe alım süreci ile ilgili araştırmanın bittiği ve sonraki maddelerin katılımcıların bazı sosyal meselelere ilişkin görüşlerinin ele alınacağ 1 farklı bir araştırma ile ilgili olacağı bilgisi verilmiştir. Ayrıca, ara metin ile katılımcıların- yer aldıklarına deney grubuna bağlı olarak- başlangıç yönergelerinde karşılaştıkları cinsiyetçi ifadelerle tekrar karşılaşmaları sağlanmıştır.

\section{Kişisel bilgi formu}

$\mathrm{Bu}$ formda yer alan üç açık uçlu madde ile katılımcılara kaç yaşında oldukları, hangi bölümde öğrenim gördükleri, kaçıncı sınıfta oldukları ve bir evet/hayır sorusu ile daha 
önce ALES’e girip girmedikleri sorulmuştur.

\section{Sözel ve sayısal alanına ilişkin cinsiyet kalıpyargılarının benimseme düzeyine ilişkin ölçüm}

Katılımcılara, kadın ve erkeklerin sözel ve sayısal alanlardaki yetkinliklerine dair inançlarını ölçen 7’li Likert tipi ( 1 = Hiç, 7 = Oldukça fazla) dört madde sunulmuştur (Örn. "Sizce, kadınlar sözel alanlarda ne kadar başarılıdır?", "Sizce, erkekler sözel alanlarda ne kadar başarılıdır?”). Bu çalışmada geçerliliği incelenen görüşlerden "kalıpyargıların aktivasyon görüşü" kadınların sözel alanda, erkeklerinse sayısal alanda daha başarılı olduklarına dair yaygın bir kanı olduğu varsayımından hareket ettiğinden, bu yaygın kanının cinsiyetçiliğin etkilerini açıklamakta etkili olup olmadığını sınamadan önce, söz konusu kanının mevcut çalışmadaki katılımcıları için geçerli olup olmadığını kontrol etme gereği duyulmuş; bu ölçüm, bu amaçla çalışmaya dâhil edilmiştir.

\section{Cinsiyetçilik algısına iliş̧kin ölçüm}

Manipülasyon kontrol sorusu olarak, katılımcıların kendilerine verilen yönergeleri cinsiyetçi algılayıp algılamadıkları "Sizce çalışmanın başında verilen yönergede cinsiyetçi ögeler bulunuyor muydu?”(Evet/Hayır/Emin Değilim) sorusu ile incelenmiştir. Bu soruyla amaçlanan, cinsiyetçilik koşullarına atanan katılımcılara verilen yönergelerin, kontrol koşulundakilerden farklı olarak, cinsiyetçiliğe maruz kaldıkları algısı yaratmada etkili olup olmadığını sınamaktır.

\section{Cinsiyetle Özdeşleşme Ölçeği}

Katılımcıların kadın kimliğine ne ölçüde bağlı olduklarını ölçmek amacıyla Luhtanen ve Crocker (1992) tarafından geliştirilen Kolektif Benlik Saygısı Ölçeğinin, kişisel benlik değeri ve kolektif benlik değeri boyutları ile ilgili olan sekiz maddesi kullanılmıştır (Örn. “Kadın olmak, kimliğimin önemli bir göstergesidir.”;"Kadın olmaya ilişkin duygularım olumludur”). Türkçe uyarlaması Amanvermez (2007, akt. Günsoy 2011) tarafindan yapılan ölçeğin maddeleri 7'li Likert formundadır ( $1=$ Kesinlikle katılmıyorum, $7=$ Kesinlikle katılıyorum). Mevcut çalışmada, katılımcıların cinsiyetleri ile özdeşleşme düzeyini ölçmek amacıyla kullanılan sekiz maddenin iç tutarlılık katsayısının .68 olduğu görülmüştür. $\mathrm{Bu}$ ölçeğe, kadınların cinsiyetçiliğe maruz kalmaları ile bilişsel performansları arasındaki ilişkide cinsiyetle özdeşleşmenin düzenleyici rolünü sınamak amacıyla çalı̧̧mada yer verilmiştir.

\section{Rosenberg Benlik Saygısı Ölçeği}

Katılımcıların benlik saygısı düzeyi Rosenberg (1965) tarafından geliştirilen Rosenberg Özsayg1 Envanterinin 12 alt ölçeğinden biri olan benlik saygısı ölçeği kullanılarak ölçülmüştür. Ölçek, dört dereceli Likert formunda ( 1 = Çok doğru, 4 = Çok yanlış) olan 10 maddeden oluşmaktadır. (Örn. "Kendimi en az diğer insanlar kadar değerli buluyorum.”; "Genel olarak kendimden memnunum"). Türkçe uyarlaması Çuhadaroğlu (1986, akt. Yumşak 2004) tarafindan yapılan ölçeğin, mevcut araştırma kapsamında elde edilen iç tutarlılık katsayısı .90'dır. Bu ölçeğe, kadınların cinsiyetçiliğe maruz kalmaları ile bilişsel performansları arasındaki ilişkide benlik saygısının düzenleyici rolünü sınamak amacıyla çalışmada yer verilmiştir. 


\section{Performans Benlik Saygısı Ölçeği}

Heatherton ve Polivy (1991) tarafından geliştirilen Durumsal Performans Benlik Saygısı Ölçeği, bireylerin bağlamla ilişkili benlik saygısını ölçmektedir. Mevcut çalışmada katılımcıların performansları ile ilişkili öz değerlendirmelerini incelemek amacıyla Durumsal Performans Benlik Saygısı Ölçeğinin alt ölçeği olan Performans Benlik Saygısı Ölçeği kullanılmıştır. Bu alt ölçek, 5’li Likert tipinde $(1=$ Kesinlikle katılmıyorum, 5 = Kesinlikle katılıyorum) yedi maddeyi içermektedir (Örn. "Konuları anlamada kendime güveniyorum.”; "Performansım hakkında hayal kırıklığı yaşıyorum.”). Balkıs ve Duru (2010) tarafından yapılan Türkçe uyarlamanın kullanıldığı bu çalışmada, ölçeğin iç tutarlılık katsayısı .71 şeklinde bulunmuştur. $\mathrm{Bu}$ ölçeğe, kadınların cinsiyetçiliğe maruz kalmaları ile bilişsel performansları arasındaki ilişkide performans benlik saygısının düzenleyici rolünü sınamak amacıyla çalışmada yer verilmiştir.

\section{Deney}

Birinci deneyde başvurulan veri toplama araçları aynı şekilde ikinci deneyde de kullanılmıştır. Cinsiyetle Özdeşleşme Ölçeği, Rosenberg Benlik Saygısı Ölçeği ve Performans Benlik Saygısı Ölçeğinin ikinci deneyde Cronbach alfa değerleri sırasıyla .72, $.87, .79$ olarak bulunmuştur.

Birinci deneyde kullanılan veri toplama araçlarına ek olarak ikinci deneye katılımcıların maruz kaldıkları yönergenin ardından deneyimledikleri duygulara ve performans motivasyonlarının düzeyine ilişkin ölçümler eklenmiştir. Ayrıca, katılımcıların cinsiyetçilik algılarına ilişkin sorularda yönergeleri ne ölçüde cinsiyetçi ve rahatsız edici algıladıkları 7 'li Likert tipinde $(1=$ Hiç, 7 = Oldukça fazla $)$ iki madde ölçülmüştür.

\section{Performans motivasyonuna ilişkin ölçüm}

Katılımcıların testte yüksek performans göstermeye yönelik motivasyon düzeylerini ölçmek amacıyla, Dardenne ve arkadaşlarının (2007) çalışmasında kullanılan sorulardan yola çıkılarak oluşturulmuş 7 'li Likert tipi $(1=$ Hiç, $7=$ Oldukça fazla $)$ beş madde kullanılmıştır. Maddelerden üçü ("Araştırma boyunca işe kabul edilmek için ne ölçüde motive oldunuz?”, “Araştırma boyunca kendinizi ispat etmeye ne derece çalıştınız?", "Araştırma kapsamında testlerden kaç puan aldığınızı öğrenmeyi ne kadar istersiniz?") katılımcıların iki testteki genel motivasyon düzeyini, biri sayısal testi çözmeye yönelik motivasyon düzeyini ("Sayısal testi yanıtlarken işe kabul edilmek adına ne ölçüde çaba sarf ettiniz?), sonuncusu ise sözel testi çözmeye yönelik motivasyon düzeyini ("Sözel testini yanıtlarken işe kabul edilmek adına ne ölçüde çaba sarf ettiniz?”) ölçmeyi amaçlamaktadır. Motivasyon düzeyi ile ilgili maddelerin Cronbach alfa katsayısı .74 şeklinde hesaplanmıştır.

\section{Deneyimlenen duygulara ilişkin ölçüm}

Cinsiyetçiliğin yol açtığı duyguları inceleyen önceki araştırmalardan yola çıkarak (Frijda ve ark. 1989, Schwarz 1990, Swim ve ark. 2001), cinsiyetçilikle karş1laşan kişilerin deneyimlemesi beklenebilecek sekiz duygu (öfke, güven, huzur, huzursuzluk, kayg1, küçümsenme, mutluluk ve aşağılanma) belirlenmiştir. Katılımcılardan, araştırma kapsamında kendilerine verilen yönergeleri dinledikten sonra sekiz duygudan her birini 
ne derecede hissettiklerini 7’li Likert tipinde ( 1 = Hiç, 7 = Oldukça fazla $)$ sekiz madde üzerinden değerlendirmeleri istenmiştir.

\section{Algılanan cinsiyetçilik ve yönergelerin rahatsız ediciliğine ilişkin ölçümler}

Katılımcılardan yönergeleri ne kadar cinsiyetçi ve ne derece rahatsız edici bulduklarını 7’li Likert tarzı (1 = Hiç, 7 = Oldukça fazla) birer madde üzerinden değerlendirmeleri istenmiştir. Bu soruyla amaçlanan, cinsiyetçilik koşullarına atanan katılımcılara verilen yönergelerin, kontrol koşulundakilerden farklı olarak, cinsiyetçiliğe maruz kaldıkları algısı ve rahatsızlık etkisi yaratmada etkili olup olmadığını sınamaktır.

\section{İşlem}

ODTÜ Uygulamalı Etik Araştırma Merkezi İnsan Araştırmaları Komitesinin 03.03.2015 tarihinde 28620816/10 sayısı ile onayladığ veriler sınıf ortamında bir araya gelen küçük gruplardan toplanmıştır. Katılımcılara öncelikle, veri toplama sürecinin peş peşe gelen iki aşamadan oluştuğu bilgisi verilerek, ilk aşamanın iş başvuruları ile ilgili deneyim kazanma olanağı bulacakları uygulamalı bir araştırma ile ikinci aşamanın ise çeşitli konulardaki tutumlarının ölçümüne dayanan başka bir araştırma ile ilgili olacağı ifade edilmiş ve katılımcıların gönüllü onamının alınmasının veri toplama sürecine geçilmiştir.

Çalışmanın birinci aşaması süresince, katılımcılardan kendilerini uzun süredir iş arayan biri gibi hayal etmeleri istenmiş, bu aşamada iş başvurularında sıkça başvurulan bir testin kullanılacağı ve testten alacakları puanların işe alımda ölçüt olarak değerlendirileceği belirtilmiştir. Ardından, katılımcılar üç deney grubundan hangisine atandıklarına bağlı olarak belirlenen bir açıklayıcı metin ile karşılaşmışlardır. Cinsiyetçiliğin değişimlenmesinin ardından BP ölçümü aşamasına geçilmiş ve katılımcıların yarısının önce sayısal testi, diğer yarısının ise önce sözel testi çözmeleri sağlanmıştır.

Sözel ve sayısal testlerin uygulanmasının hemen ardından, katılımcılara sunulan bir ara metin ile oturumun birinci aşamasının bittiği bilgisi verilmiş ve ikinci aşamada farklı bir araştırma için sosyal konulardaki görüşlerinin alınacağı belirtilerek ilgili ölçek maddeleri ve demografik bilgi formu sunulmuştur.

\section{İstatistiksel analiz}

Her iki deneyin istatistiksel analizleri SPSS 22 programı kullanılarak yapılmıştır. İki deneyde de katılımcıların, kadınları sözel ve sayısal alanlarda ne derece yetkin algıladıkları Eşleştirilmiş Gruplar T Testi kullanılarak karşılaştırılmış, böylece kadınlarda sözel becerilerin sayısal becerilerden daha yüksek olduğuna dair geleneksel cinsiyet kalıpyargısını kabul edip etmedikleri sınanmıştır. Benzer şekilde, erkeklerde sayısal becerilerin sözel becerilerden daha yüksek olduğuna dair kalıpyargıyı kabul edip etmediklerini sınamak üzere, katılımcıların erkekleri sözel ve sayısal alanlarda ne derece yetkin algıladıkları da Eşleştirilmiş Gruplar T Testi kullanılarak karşılaştırılmıştır. Ayrıca, uygulanan bir dizi tek yönlü varyans analizi ile deneysel manipülasyonun sonuç değişkenleri üzerindeki etkileri saptanmı̧stır. Her iki deneyde cinsiyetçiliğe maruz kalma ve sergilenen test performansı arasındaki ilişkide aracı ve düzenleyici rol oynayan değişkenlerin etkileri, Hayes'in (2013) PROCESS makrosu ile SPSS üzerinden test edilmiştir. 
İki deneyde ortak kullanılan analizlerden farklı olarak, çalısmanın ilk deneyinde katılımcıların kendilerine sunulan yönergelerin cinsiyetçi olup olmadığına ilişkin değerlendirmelerinin, hangi araştırma koşulunda yer aldıklarına bağılı olarak değişeceği beklentisi, verileri Ki Kare Bağımsızlık Testi ile analiz ederek sınanmıştır.

İkinci deneyde ise, farklı deney gruplarında yer alan katllımciların kendilerine sunulan yönergeleri ne kadar cinsiyetçi ve rahatsız edici algilandıkları tek yönlü varyans analizi ile incelenmiştir. İkinci deneyde tüm değişkenlerin birbiri ile ilişkisini incelemek üzere Pearson korelasyon analizleri, örneklemin tamamı üzerinde uygulanmıştır. Ayrıca, yine ikinci deneyde cinsiyetçiliğe maruz kalma sonucunda ortaya çıkan çeşitli duygular ve katılımcıların cinsiyet kimliğiyle özdeşleşme düzeyleri arasındaki ilişki, üç ayrı araştırma koşulu için ayrı ayrı yapılan Pearson korelasyonları ile incelenmiştir.

\section{Bulgular}

\section{Deney}

\section{Cinsiyetçiliğin algılanması}

Deney esnasında kendilerine sunulan çeşitli metinler aracilığıyla KC veya DC'ye maruz bırakılan katılımcıların metinlerdeki cinsiyetçiliği algılayıp algılamadıklarını test etmek üzere, karşılaştıkları ifadeleri ne ölçüde cinsiyetçi bulduklarına dair değerlendirmeleri, kontrol koşulundaki katılımcıların değerlendirmeleriyle Ki-Kare Bağımsızlık Testi kullanılarak kıyaslanmıştır. Analizler, katılımcıların hangi deney grubunda yer aldıklarının, durumu cinsiyetçi değerlendirilmeleri ile ilişkisinin anlamlı olduğunu göstermiştir, X2 (4) = 15.40, p <.05. Kontrol koşulundakilerle (\%20) kıyaslandığında, KC (\%47) ve DC (\%33) koşullarında yer alanların, karşılaştıkları yönergeleri daha cinsiyetçi algıladıkları görülmüştür.

\section{Cinsiyetlere yönelik kalıpyargıların benimsenmesine ilişkin analizler}

Araştırmaya katılan kadınların sözel ve sayısal performans alanlarına ilişkin cinsiyet kalıpyargılarını ne düzeyde benimsediklerini incelemek üzere, sözel ve sayısal alanlarda kadın ve erkekleri ne denli yetkin gördükleri ile ilgili kendilerine sunulan maddelere verdikleri yanıtlar, Eşleştirilmiş Gruplar T-Testi aracilığıyla incelenmiştir. Sonuçlar, katılımciların sayısal alanda kadınlara kıyasla (Ort. $=4.93 ; \mathrm{S}=1.09)$ erkekleri (Ort. = 5.88; $\mathrm{S}=0.88)$; sözel alanda ise erkeklere kıyasla (Ort. = 4.50; $\mathrm{S}=1.29)$ kadınları (Ort. = $6.11 ; \mathrm{S}=0.94)$ daha yetkin değerlendirdiklerini ortaya koymuştur, sırasıyla $t(79)=7.08, \mathrm{p}$ $<.05 ; \mathrm{t}(79)=9.92, \mathrm{p}<.05 . \mathrm{Bu}$ analiz sonuçları erkeklerin sayısal, kadınlarınsa sözel alanda başarılı olduklarına dair cinsiyet kalıpyargılarının bu çalışmanın katılımciları tarafından büyük ölçüde benimsendiğine işaret etmektedir.

\section{Cinsiyetçiliğe maruz kalmanın test performansları üzerindeki etkisi}

Araştırmanın temel amacı DC ve KC'ye maruz kalmanın kadınların sözel ve sayısal test performansları üzerinde anlamlı etkisi olup olmadığını belirlemektir. Bu amaçla ilk olarak, katılımciların hangi deney koşulunda yer aldıklarının sözel puanlarına etkisi tek yönlü varyans analizi (ANOVA) ile incelenmiş, ardından sayısal puanlar üzerinde aynı analiz uygulanmıştır. Tablo 1'de görüldüğü üzere, farklı deney gruplarında yer alan katılımciların sözel testteki doğru yanıt sayıları anlamlı şekilde birbirinden farklılaşmaktadır, F2,77 = 7.82, p < .01, ฤ2=.17 (bknz. Tablo 1). Tukey yöntemi 
kullanılarak yapılan çiftler arası karşılaştırmalar, DC ifadelerle karşılaşan kadınların (Ort. $=6.18, \mathrm{~S}=1.84), \mathrm{KC}$ ifadelere maruz kalanlar (Ort. = 4.42, $\mathrm{S}=1.67)$ ile kıyaslandığında sözel testte daha fazla soruyu doğru yanıtladıklarını göstermiştir. Kontrol koşulunda yer alan katılımcıların sözel performansları ise (Ort. $=5.16, \mathrm{~S}=1.40) \mathrm{KC}$ ve DC koşulunda bulunan katılımcılardan anlamlı şekilde farklılaşmamıştır. Sayısal testte ilişkin yapılan varyans analizi sonuçları, yer alınan deney grubunun sergilenen sayısal performansı üzerinde anlamlı bir etkiye sahip olmadığını ortaya koymuştur, F2,77 = 0.70, p >.05.

\section{Cinsiyetle özdeşleşme ve benlik saygısının düzenleyici rolü}

Yukarıda görüldüğü gibi, varyans analizi sonuçları deney gruplarının yalnızca sözel test performansında birbirinden farklılaştığını göstermiştir. Bunun ardından, cinsiyetçiliğe maruz kalma ve sözel performans arasındaki ilişkide, cinsiyetle özdeşleşme ve benlik sayg1sı değişkenlerinin düzenleyici rolü olup olmadığı sorusunu cevaplandırmaya yönelik analizler yapılmıştır. Cinsiyetle özdeşleşme düzeyinin düzenleyici rolünün sınandığı analizler, maruz kalınan cinsiyetçilik türü ve sözel performans arasındaki ilişkiye olan düzenleyici etkisinin istatistiksel açıdan anlamlı olmadığı bulunmuştur, $\beta=.05 ; \mathrm{t}(76)=$ $1.21, \mathrm{p}>0.05$.

Benlik saygısının düzenleyici rolü ile ilgili analizler, katılımcıların sahip olduğu genel benlik saygisının $[\beta=.08 ; \mathrm{t}(76)=1.77, \mathrm{p}>0.05]$ ve performans benlik saygisının $[\beta=$ $.11 ; \mathrm{t}(76)=1.95, \mathrm{p}>0.05]$ yer alınan deney grubu ve sergilenen sözel performans arasındaki ilişkide anlamlı düzenleyici rolü olmadığını ortaya koymuştur.

\section{Deney}

\section{Cinsiyetçiliğin algılanması ve rahatsız edici olarak nitelendirilmesi}

Katılımcıların sunulan yönergeleri cinsiyetçi ve rahatsı edici değerlendirme düzeylerinin hangi deney grubunda yer aldıklarına göre farklılaşıp farklılaşmadığı, tek yönlü varyans analizi ile incelenmiştir. Analizlerin sonucunda, farklı deney gruplarında yer alan katılımcıların yönergeleri hem cinsiyetçi $(\mathrm{F} 2,153=6.65, \mathrm{p}<.05, \eta 2=.08)$ hem de rahatsız edici değerlendirme düzeyleri açısından farklılaştıkları görülmüştür, $(\mathrm{F} 2,153=$ $4.81, \mathrm{p}<.05, \eta 2=.06)$. Tukey yöntemi ile yapılan çiftler arası karşılaştırmalar, DC koşulu (Ort. $=4.86, \mathrm{~S}=1.90)$ ve $\mathrm{KC}$ koşulunda (Ort.= 4.70, $\mathrm{S}=2.05$ ) yer alan katılımcıların, verilen yönergeleri cinsiyetçi olarak değerlendirme düzeylerinin kontrol koşulundakilerden (Ort. = 3.47, S = 2.38) yüksek olduğunu açığa çıkarmıştır. Benzer şekilde, DC koşulundaki (Ort. $=2.73, \mathrm{~S}=2.07$ ) ve $\mathrm{KC}$ koşulundaki (Ort. $=2.63, \mathrm{~S}=$ 1.72) kadınlar, kontrol koşulundakilere $($ Ort. $=1.79, \mathrm{~S}=1.25)$ kıyasla yönergeleri daha rahatsız edici değerlendirmişlerdir.

\section{Cinsiyetlere yönelik kalıpyargıların benimsenmesine ilişkin analizler}

Araştırmaya katılan kadınların sözel ve sayısal alanlarda cinsiyetleri hedef alan kalıpyargıları ne ölçüde benimsediğini gösteren Eşleştirilmiş Gruplar T Testi Analizi sonuçları, birinci deneyden elde edilen sonuçlarla paraleldir. Katılımcıların kadınları sözelde (Ort. $=6.06 ; \mathrm{S}=0.87$ ) erkeklere $($ Ort. $=4.06 ; \mathrm{S}=1.34)$ oranla daha yetkin gördükleri, erkekleri (Ort. $=5.63 ; \mathrm{S}=1.14)$ ise sayısalda kadınlara (Ort. $=4.74 ; \mathrm{S}=1.27$ ) kıyasla daha başarılı değerlendirdikleri anlaşılmıştır, $\mathrm{t}(155)=14.73, \mathrm{p}<.01 ; \mathrm{t}(155)=6.53$, $\mathrm{p}<.01$. 


\section{Test performanslanının diğer değişkenlerle ilişkisi}

Öncelikle, sözel ve sayısal test performanslarının araştırma kapsamında kullanılan diğer değişkenlerle ilişkilerini incelemek amacıyla korelasyon analizi uygulanmıştır. Tablo 2'de görüldüğü üzere, katılımcıların sözel test performanslarının hissettikleri öfke duygusu ile pozitif yönde anlamlı korelasyonu bulunmaktadır, $\mathrm{r}(154)=.20, \mathrm{p}<.05$, (bknz. Tablo 2). Ayrıca, katılımcıların sözel test performansı testlere yönelik motivasyon düzeyleri ile de pozitif ilişki göstermiştir, $\mathrm{r}(154)=.18, \mathrm{p}<.05$. Öte yandan, katılımcıların sayısal testte sergiledikleri performans, etkisi incelenen hiçbir değişkenle anlamlı ilişki göstermemiştir. Özetle, korelasyon analizi sonuçları kadınların karşılaştıkları cinsiyetçi ögelerin ardından öfke hissettikçe ve testlere yönelik motivasyonları arttıkça sözel testte gösterdikleri başarılarının da arttığını, matematik performanslarında ise bir değişim olmadığını göstermiştir.

Sonraki adımda, öfke ve motivasyon düzeyinin sözel performansla ilişkisini daha detaylı bir şekilde anlamak adına, söz konusu değişkenlerin test performansı ile korelasyonu her bir deney grubunda yer alan katılımcılar için ayrı ayrı ele alınmıştır. Yapılan analizler sonucunda, öfke duygusu ve sözel performans arasındaki ilişkinin üç koşul için aynı olmadığı anlaşılmıştır. Sonuçlara göre, KC koşulunda ve kontrol grubunda yer alan katılımcılar için öfke ve sözel performans arasındaki ilişki anlamlı düzeyde değildir, sırasıyla $r(54)=.06, p>.05 ; r(53)=.02, p>.05$. Fakat DC'ye maruz kalan kadınlar için söz konusu ilişkinin pozitif ve anlamlı olduğu görülmüştür, $r(49)=$ $.32, \mathrm{p}<.05$. Benzer şekilde, sözel performans ile motivasyon düzeyi arasındaki pozitif ilişki KC koşulunda ve kontrol koşulunda yer alan kadınlar için anlamlı değildir, $r(54)=$ $.03, \mathrm{p}>.05 ; \mathrm{r}(53)=.15, \mathrm{p}>.05$. DC'ye maruz kalan kadınlar için ise ele alınan ilişkinin istatistiksel açıdan anlamlı ve pozitif olduğu anlaşılmı̧̧ır, $r(49)=.27, \mathrm{p}<.05$.

\section{Cinsiyetçiliğe maruz kalmanın test performansları üzerindeki etkileri}

Maruz kalınan cinsiyetçilik türünün test performansları üzerinde anlamlı etkiye sahip olup olmadığını belirlemek amacıyla yapılan varyans analizi sonuçlarına göre, deney gruplarının sözel testteki performansları anlamlı şekilde birbirinden farklılaşmıştır, F 2, $153=4.42, \mathrm{p}<.05, \eta 2=.06$. Tablo 1'de görüldüğü üzere, DC koşulundaki kadınların sözel testte sergilediği performans (Ort. $=5.41, \mathrm{~S}=1.55$ ) hem $\mathrm{KC}$ koşulundakilerin (Ort. $=4.59, \mathrm{~S}=1.56)$ ve hem de kontrol koşulundakilerin (Ort. $=4.60, \mathrm{~S}=1.62$ ) performansindan daha yüksektir (Tablo 1).

Tablo 1. Birinci ve ikinci çalışmada farklı deney gruplarının sözel ve sayısal testlerdeki performansları

\begin{tabular}{|c|c|c|c|c|c|c|c|}
\hline & & $\begin{array}{c}\text { Korumacı } \\
\text { (SS) }\end{array}$ & $\begin{array}{c}\text { Kontrol } \\
\text { (SS) }\end{array}$ & Düşmanca (SS) & $\mathbf{F}$ & $\begin{array}{c}\text { Anlamlılık } \\
\text { düzeyi }\end{array}$ & $\begin{array}{c}\text { Eta } \\
\text { değeri } \\
\eta^{2}\end{array}$ \\
\hline \multirow{2}{*}{ むั } & $\begin{array}{l}\text { Sözel } \\
\text { Performans }\end{array}$ & $\begin{array}{l}4.42^{\mathrm{a}} \\
(1.67)\end{array}$ & $5.16^{\mathrm{ab}}(1.40)$ & $6.18^{b}(1.84)$ & 7.82 & 0.01 & 0.17 \\
\hline & $\begin{array}{l}\text { Sayısal } \\
\text { Performans }\end{array}$ & $\begin{array}{l}3.82^{\mathrm{a}} \\
(1.59)\end{array}$ & $3.32^{\mathrm{a}}(1.31)$ & $3.70^{\mathrm{a}}(1.84)$ & 0.70 & 0.50 & 0.02 \\
\hline \multirow{2}{*}{ 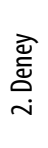 } & $\begin{array}{l}\text { Sözel } \\
\text { Performans }\end{array}$ & $\begin{array}{l}4.59^{a} \\
(1.56)\end{array}$ & $4.60^{\mathrm{a}}(1.62)$ & $5.41^{b}(1.55)$ & 4.42 & .01 & 0.06 \\
\hline & $\begin{array}{l}\text { Sayısal } \\
\text { Performans }\end{array}$ & $\begin{array}{l}3.55^{\mathrm{a}} \\
(2.31)\end{array}$ & $3.06^{\mathrm{a}}(2.62)$ & $3.92^{\mathrm{a}}(2.73)$ & 1.46 & .23 & 0.02 \\
\hline
\end{tabular}

Not. Farklı üst simgelere sahip ortalamalar $p<.01$ düzeyinde anlamlıdır 
Tablo 2. İkinci çalışma kapsamında kullanılan değişkenlerin birbiri ile korelasyonu

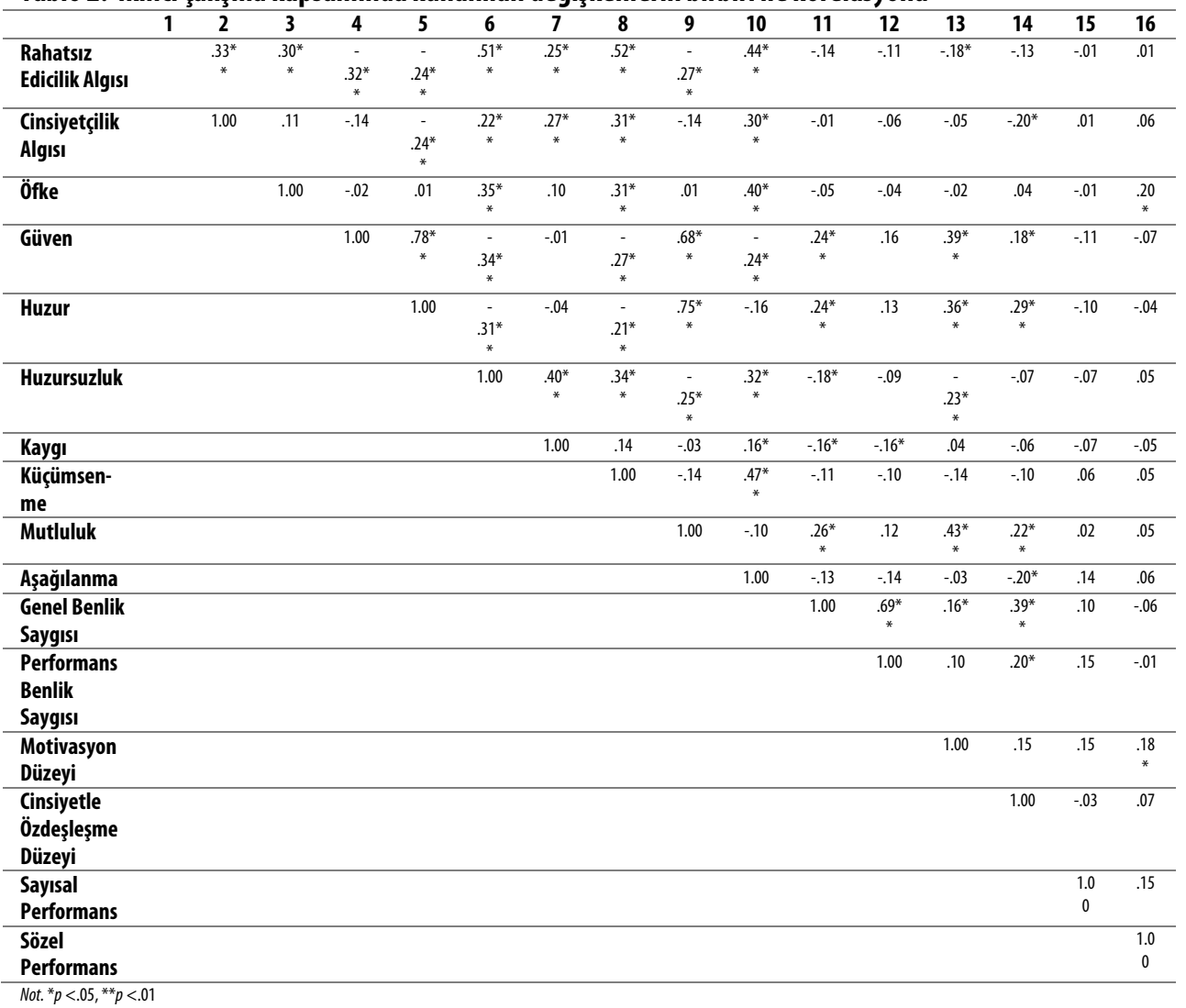

Sayısal teste gelindiğinde, birinci deneyin bulgularına paralel şekilde, üç farklı deney grubunda yer alan katılımcıların sayısal testte sergiledikleri performansın birbirinden ayrışmadığ 1 görülmüştür, F 2, $153=1.46$, p >.05.

\section{Cinsiyetçiliğe maruz kalmanın deneyimlenen duygular ve motivasyon düzeyi üzerindeki etkileri}

Kadınların öfke, güven, huzur, huzursuzluk, kaygı, küçümsenme, mutluluk ve aşağılanma duygularını deneyimleme düzeylerinin, hangi deney koşulunda yer aldıklarına göre değişip değişmediği bir dizi tek yönlü bir gruplar arası varyans analizi kullanılarak incelenmiş ve sonuçlar Tablo 3'te sunulmuştur (Tablo 3). Sonuçlara göre, katılımciların hangi deney koşulunda yer aldıkları, onların öfke, küçümsenme ve aşağılanma hislerini ne düzeyde yaşadıklarını etkilemiştir, öfke için (F2, $153=7.00, p<.05, \eta 2=.08)$; küçümsenme için $(\mathrm{F} 2,153=4.22, \mathrm{p}<.05, \eta 2=.05)$; aşağ1lanma için $(\mathrm{F} 2,153=6.14, \mathrm{p}<$ $.05, \eta 2=.07)$. Tukey yöntemi ile yapılan çiftler arası karşılaştırmaların sonuçlarına göre DC koşulundaki kadınlar (Ort. = 3.57; $\mathrm{S}=2.28), \mathrm{KC}$ koşulundakilere (Ort. $=2.59 ; \mathrm{S}=$ 1.82) ve kontrol koşulundakilere (Ort. $=2.16 ; \mathrm{S}=1.67$ ), göre daha yüksek derecede öfke beyan etmiştir. DC koşulunda yer alan kadınların (Ort. $=2.35 ; \mathrm{S}=1.95$ ) deneyimledikleri aşağılanma hissi, $\mathrm{KC}$ koşulunda yer alanlarınkinden (Ort. $=1.72 ; \mathrm{S}=$ 1.32) farklılaşmazken; kontrol grubundakilerden (Ort. = 1.32; S = 1.08) anlamlı düzeyde 
daha yüksek bulunmuştur. Küçümsenme hissi ile ilgili yapılan analizler KC koşulundaki kadınların (Ort. $=2.35 ; \mathrm{S}=1.90)$ kontrol koşulundakilere (Ort. $=1.49 ; \mathrm{S}=0.95$ ) göre daha yüksek derecede küçümsenme deneyimlediklerini göstermiştir. DC koşulundaki katılımcıların deneyimledikleri küçümsenme hissi (Ort. $=2.04 ; \mathrm{S}=1.63$ ) ise diğer koşullardaki katılımcıların deneyimledikleri küçümsenme hissinden anlamlı şekilde farklılaşmamıştır.

Cinsiyetçi ifadelere maruz kalmanın kadınların performans motivasyonuna etkilerini incelemek üzere yapılan varyans analizinin sonuçları, katılımcıların performans motivasyonlarının, yer aldıkları deney grubuna göre değişmediğine işaret etmiştir, F2, $153=0.87, \mathrm{p}>.05$.

Tablo 3. İkinci çalışmada deney gruplarına göre deneyimlenen duyguların ortalama değerleri ve varyans analizi sonuçları

\begin{tabular}{lccccc}
\hline & Korumacı (SS) & Kontrol (SS) & Düşsmanca (SS) & F & Eta değeri $\eta^{2}$ \\
\hline Öfke & $2.59^{\mathrm{a}}(1.82)$ & $2.16^{\mathrm{a}}(1.67)$ & $3.57^{\mathrm{b}}(2.28)$ & 7.00 & .084 \\
\hline Güven & $4.50^{\mathrm{a}}(1.82)$ & $4.74^{\mathrm{a}}(1.98)$ & $4.57^{\mathrm{a}}(1.76)$ & 0.23 & .003 \\
\hline Huzur & $3.91^{\mathrm{a}}(1.44)$ & $4.25^{\mathrm{a}}(2.07)$ & $3.98^{\mathrm{a}}(1.89)$ & 0.51 & .007 \\
\hline Huzursuzluk & $3.11^{\mathrm{a}}(1.89)$ & $2.49^{\circ}(1.55)$ & $3.04^{\mathrm{a}}(1.93)$ & 1.89 & .024 \\
\hline Kaygı & $3.87^{\mathrm{a}}(1.98)$ & $3.62^{\mathrm{a}}(1.95)$ & $3.63^{\mathrm{a}}(1.82)$ & 0.28 & .004 \\
\hline Küçümsenme & $2.35^{\mathrm{a}}(1.90)$ & $1.49^{\mathrm{b}}(0.95)$ & $2.04^{\mathrm{a}}(1.63)$ & 4.22 & .052 \\
\hline Mutluluk & $3.83^{\mathrm{a}}(1.70)$ & $4.04^{\mathrm{a}}(1.96)$ & $3.78^{\mathrm{a}}(1.78)$ & 0.30 & .004 \\
\hline Aşağı̆lanma & $1.72^{\mathrm{a}}(1.32)$ & $1.32^{\mathrm{a}}(1.08)$ & $2.35^{\mathrm{b}}(1.95)$ & 6.14 & .074 \\
\hline
\end{tabular}

Not. Farklı üst simgelere sahip ortalamalar $p .01$ düzeyinde anlamlıdır.

\section{Öfke duygusunun aracı rolü}

Katılımcıların sözel performansında farklılaşma yarattığı görülen tek duygu öfkedir. Dolayısıyla, bu çalı̧̧mada cinsiyetçiliğe maruz kalma ve test performansı arasındaki ilişkide deneyimlenen öfke düzeyinin aracı rolü SPSS Macro analizi ile incelenmiştir (Şekil 1). Kontrol koşulunun referans kategorisi olarak belirlendiği aracılık analizinde kukla değişkenler kullanılmıştır. Analiz sonuçlarında, cinsiyetçi olmayan talimatlarla karşılaşan katılımcılarla kıyaslandığında düşmanca cinsiyetçiliğe maruz kalan kadınların, sözel testte daha iyi performans sergilediği bulunmuştur $(\mathrm{c} 1=0.80, \mathrm{p}=.01)$. KC ile karşılaşan katılımcılarla kontrol koşulundaki katılımcıların sözel performansları arasında ise anlamlı bir farklilik yoktur $(\mathrm{c} 2=-0.01, \mathrm{p}>.05)$. Ayrica, kontrol grubunda yer alan katılımcılarla karşılaştırıldığında, DC koşulundaki kadınların deneysel manipülasyondan sonra daha fazla öfke bildirdikleri görülürken $(\mathrm{a} 1=2.05 \mathrm{p}<.001)$; KC ile karşılaşan kadınların öfke düzeyleri ile kontrol koşulundaki kadınların öfke düzeyleri arasında anlamlı bir farklılık olmadığı anlaşılmıştır $(\mathrm{a} 2=0.35 \mathrm{p}>.05)$.

Katılımcıların deneyimledikleri öfke duygusu kontrol edildiğinde ise düşmanca cinsiyetçilikle karşılaşan kadınların sözel test performanslarının kontrol koşulundakilerden farklılaşmadığ1 gözlenmiştir $\left(c^{\prime} 1=0.49, \mathrm{p}=, 14\right)$. Öfke duygusu kontrol edildiğinde, korumacı cinsiyetçilik ve kontrol koşulunda yer alan kadınların sözel performansları arasındaki benzerliğin devam ettiği bulunmuştur $\left(c^{\prime} 2=-0.06, p>.05\right)$. Ayrıca, cinsiyetçilikten sonra daha fazla öfke yaşayan katılımcıların sözel testte daha iyi bir performans sergiledikleri ortaya konmuştur $(b=0.15, p<.05)$. Özetlemek gerekirse, aracı değişken analizi sonucunda düşmanca cinsiyetçilik ile karşılaşan katılımcıların kontrol koşulunda yer alanlarla kıyaslandığında daha fazla öfke yaşadıkları ve bu etkinin düşmanca cinsiyetçilik koşulunda yer alan katılımcıların sözel test performansının 
yükselmesine katkı sağladığ1 bulunmuştur (nokta tahmini $=0.306, \% 95$ GA: 0.331, 0.661). Yani, öfke duygusunun sözel performans üzerinde doğrudan etkisi yoktur. Yapılan analizler sonucunda öfke duygusunun korumacı cinsiyetçilik ve sözel performans ilişkisine ise aracılık etmediği ortaya çıkmıştır (nokta tahmini $=0.032, \% 95$ GA: -0.028 , 0.125).
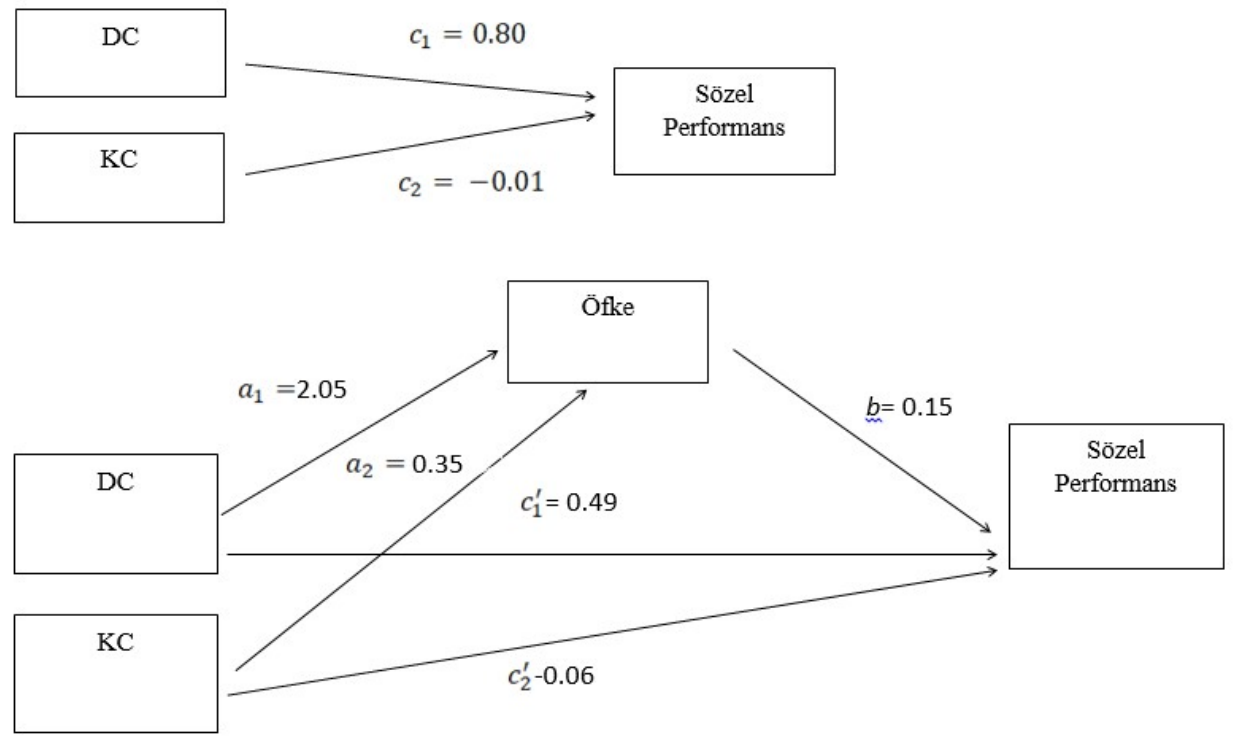

$a_{1}$ ve $a_{2}$ : Düşmanca ve korumacı cinsiyetçiliğin öfke üzerindeki etkisi $c_{1}$ ve $c_{2}$ : Düşmanca ve korumacı cinsiyetçiliğin sözel performans üzerindeki toplam etkisi $c_{1}^{\prime} v c_{2}^{\prime}$ : Düşmanca ve korumacı cinsiyetçiliğin sözel performans üzerindeki doğrudan etkisi $a_{1} b$ ve $a_{2} b$ : Düşsmanca ve korumacı cinsiyetçiliğin sözel performans üzerindeki dolaylı etkisi Şekil 1. İkinci çalışmada uygulanan aracılık analizinde toplam, doğrudan ve dolaylı etkiler

\section{Cinsiyetle özdeşleşme ve benlik saygısının düzenleyici rolü}

İkinci deneyden elde edilen bulgular, tıpkı birinci deneyde olduğu gibi, deney gruplarının test performanslarının yalnızca sözel alanda birbirinden farklılaştığını ortaya koymuştur. $\mathrm{Bu}$ nedenle, ikinci deneyde sergilenen performans ve deney koşulları arasındaki ilişkide düzenleyici değişkenlerin oynadıkları rol, yalnızca sözel test için incelenmiştir.

Analizler sonucunda, bireylerin cinsiyetle özdeşleşme düzeyinin, maruz kaldıkları cinsiyetçilik türü ile sergiledikleri sözel performans arasındaki ilişkiye olan düzenleyici etkisinin istatistiksel açıdan anlamlı olmadığ bulunmuştur, $\beta=.02 ; \mathrm{t}(152)=.63, \mathrm{p}$ > 0.05. Benzer şekilde, maruz kalınan cinsiyetçilik türü ve sergilenen sözel performans arasındaki ilişkide, katılımcıların ne genel benlik saygısı düzeyinin ne de performans benlik saygısı düzeyinin düzenleyici rolü anlamlıdır, sırasıyla $\beta=-.01 ; \mathrm{t}(152)=-.34, \mathrm{p}>$ 0.05 ve $\beta=.06 ; \mathrm{t}(152)=1.88, \mathrm{p}>0.05$.

\section{Deney grupları için cinsiyetle özdeşleşme ve deneyimlenen duygular arasındaki ilişki}

Kadınların cinsiyetçilik deneyimi ardından hissettikleri duyguların, cinsiyetleri ile özdeşleşme düzeyi ile ilişkili olabileceği düşünülmüştür. Bu nedenle, deneyimlenen duygular ve kadınların cinsiyetleri ile özdeşleşme düzeyleri arasındaki ilişki her bir deney 
grubu için ayrı ayrı incelenmiştir. Tablo 4'te gösterildiği üzere, DC'ye maruz kalan kadınlarda aşağılanma $(r=.30, p<.05)$ ve huzursuzluk $(r=-.32, p<.05)$ hisleri, cinsiyetle özdeşleşme ile anlamlı ilişki göstermiştir (bknz. Tablo 4). DC ile karşılaşan kadınların cinsiyetle özdeşleşme düzeyi arttıkça, cinsiyetçiliğin ardından deneyimledikleri aşağılanma hissi artmış; fakat huzursuzluk hissi azalmıştır. Duygular ve özdeşleşme arasındaki ilişki kontrol grubu için ele alındığında, güvenlik $(r=.34, p<.05)$, huzur $(r=$ $.43, \mathrm{p}<.01)$ ve mutluluk $(\mathrm{r}=.41, \mathrm{p}<.01)$ hislerinin özdeşleşme düzeyi ile pozitif ilişkili olduğu bulunmuştur.

Tablo 4. İkinci çalışmada deney gruplarına göre deneyimlenen duygular ve cinsiyetle özdeşleşme düzeyi arasındaki korelasyon

\begin{tabular}{lcccccccc}
\hline & Öfke & Güven & Huzur & Huzursuzluk & Kaygı & Küçümsenme & Mutluluk & Aşağılanma \\
\hline $\begin{array}{l}\text { Korumacı } \\
\text { Cinsiyetçilik }\end{array}$ & .07 & -.04 & .17 & .10 & .02 & -.01 & .00 &.-17 \\
\hline $\begin{array}{l}\text { Düssmanca } \\
\text { Cinsiyetçilik }\end{array}$ & .06 & .23 & .21 & $-.32^{*}$ & -.16 & -.24 & .20 & $.30^{*}$ \\
\hline Kontrol Grubu & .02 & $.34^{*}$ & $.43^{* *}$ & .01 & -.05 & .02 & $.41^{* *}$ & .09 \\
\hline
\end{tabular}

Not. ${ }^{*} p<.05,{ }^{* *} p<.01$

\section{Tartışma}

Mevcut araştırmanın ilk deneyinde öncelikle, deneysel müdahalenin çalışıp çalışmadığını incelemek amacıyla, farklı deney gruplarında yer alan katılımcıların kendilerine sunulan yönergeleri cinsiyetçi bulup bulmadıkları karşılaştırılmıştır. Korumacı ve düşmanca cinsiyetçi ifadelere maruz kalan kadınların kendilerine sunulan yönergeleri cinsiyetçi olarak nitelendirme eğiliminin, kontrol grubunda yer alanlardan yüksek olduğunun yapılan analizlerle gösterilmiş olması sebebiyle, uygulanan deneysel müdahalenin işlediğine karar kılınmıştır. Öte yandan, bu ilk deneyde yönergelerin cinsiyetçi algılanma düzeyi ile ilgili kullanılan evet/hayır sorusunun katılımcıları sınırlandırıcı ve yönlendirici olabileceği düşünüldüğünden, ikinci deneyde yönergelerin ne ölçüde cinsiyetçi algılandığ1 Likert tarzında bir madde ile ölçülmüştür. Cinsiyetçiliğin algılanması ile ilgili ikinci deneyden gelen bulgular da birinci deney bulguları ile benzer niteliktedir. İkinci deney bulgularında da hem DC cinsiyetçilik hem de KC koşullarında yer alan katılımcıların, karşılaştıkları yönergeleri cinsiyetçi algılama ve bu yönergelerden rahatsızlık duyma eğilimlerinin, hiçbir cinsiyetçilik ögesi ile karşılaşmayan kontrol grubundakilerden daha yüksek olduğu görülmüş̧ür. KC'ye ve DC'ye maruz kalanların, karşılaştıkları durumu eşit derecede cinsiyetçi ve rahatsız edici algılamış olması, tartışılmaya değer bir sonuçtur. Cinsiyetçiliğin örtük bir dille ifade edilmesi, kadınların kullanılan cinsiyetçi tınıyı fark etmelerine engel olmamıştır. Literatürde, kadınların DC ve KC arasındaki ilişkiyi fark edemedikleri iddiasını destekleyen çalışma olduğu gibi (Kilianski ve Rudman 1998), bu ikisinin birlikteliğinin farkında oldukları iddiasını destekleyen çalışmalar da bulunmaktadır (Bohner ve ark. 2010). Mevcut çalışma ise, bu iddialardan ikincisini destekleyecek nitelikte yeni bir bulgu üretmiştir. Elde edilen bulgular, kadınların cinsiyetçiliğin her tür formuna karşı uyanık olduklarına işaret etmesi sebebiyle, umut vericidir.

Araştırma kapsamında gerçekleştirilen iki deneyden elde edilen ortak bulgulardan bir diğeri kadınların sözel, erkeklerin ise sayısal alanda daha başarılı olduğuna yönelik kalıpyargıların araştırmanın katılımcıları tarafından benimsendiği bulgusudur. Çalışma kapsamında, cinsiyetçiliğin kadınların bilişsel görevlerde sergiledikleri performans 
üzerindeki yansımalarının incelenmesi için sözel ve sayısal alanların seçilme nedenlerinden birisi, bu alanlarda cinsiyetlerin yetkinliğine ilişkin yaygın şekilde kabul gören kalıpyargıların olmasıdır. İki deneyden gelen bulgular, ilgili alanlardaki kalıpyargıların araştırmanın katılımcıları tarafından benimsendiğini ve bilişsel performansta bu alan seçiminin araştırmanın amacına uygun, yerinde bir tercih olduğunu ortaya koymuştur.

Araştırmanın temel amacı olan korumacı ve düşmanca cinsiyetçiliğin bilişsel performansa etkilerinin incelendiği analizlerde, birinci deneyden gelen bulgular Dardenne ve arkadaşlarının (2007) elde ettiği sonuçlardan farklı olarak- cinsiyetçiliğe maruz kalmanın etkileri üzerine ileri sürülen görüşlerden "istenmeyen düşünceler" görüşünü desteklememiştir. Birinci deneyde, ne KC ne de DC koşullarındaki kadınların sözel ve sayısal puanları kontrol koşulundakilerden farklı bulunmuştur; ancak sözel alandaki performans, DC'ye maruz kalanlarda KC'ye maruz kalanlardan daha yüksektir. Performans farkının sadece sözel alanda ortaya çıkması ve DC'ye maruz kalanların aldıkları puanın daha yüksek oluşu, kısmen de olsa öfke-temelli tepki görüşüne destek olarak kabul edilebilir. Bu nedenle, uğradıkları ayrımcılığın kadınlarda hangi duyguları açığa çıkardığını incelemek adına yeni bir çalışma gereksinimi ortaya çıkmış ve böylece aynı deney yönteminin kullanıldığı ikinci deney gerçekleştirilmiştir. Çalışmanın ikinci deneyinde, ilk çalışmanın sonuçlarıyla benzer biçimde, maruz kalınan cinsiyetçiliğin test performansı üzerindeki etkisinin kullanılan testin içeriği ile ilişkili olduğu görülmüştür. Şöyle ki, farklı deney koşullarındaki kadınların sayısal testteki performansları benzer düzeyde iken, sözel testteki performansları farklıdır: DC koşulunda yer alan kadınların sözel performansı hem $\mathrm{KC}$ hem de kontrol koşulunda yer alan kadınlardan daha yüksektir. Bu sonuçlardan yola çıkarak, karşılaştıkları cinsiyetçilik ögelerinin kadınların tüm bilişsel becerilerini aynı yönde etkilemediği anlaşılmıştır. Cinsiyetçiliğin etkisinin farklı alanlarda farklı şekilde ortaya çıktığını gösteren bu sonuçlar, araştırmadan elde edilen kıymetli bulgular arasındadır.

İkinci deneyden cinsiyetçiliğe maruz kalma ve ardından deneyimlenen duygular arasındaki ilişkiye dair elde edilen sonuçlar, önceki çalışmaları destekler niteliktedir (Örn. Barreto ve Ellemers 2005, Becker ve Wright 2011). DC ile karş1laşan kadınların, beklendiği gibi, diğer iki koşulda yer alan katılımcılardan daha yüksek düzeyde öfke deneyimlediği bulunmuştur. Ayrıca, KC'ye maruz kalan kadınlar küçümsenme, DC koşulundakiler ise aşağılanma hissini kontrol koşulundaki kadınlardan daha yüksek düzeyde rapor etmişlerdir. Cinsiyetçiliğe maruz kalma ve ardından deneyimlenen duygular ile ilgili elde edilen sonuçların Bilişsel Ayarlama Modelinin (Schwarz 1990) beklentileri ile uyumlu olduğu düşünülmektedir. Tam da modelde ileri sürüldüğü gibi, belirgin bir tehdit unsuru ile karşılaşan $\mathrm{KC}$ ve $\mathrm{DC}$ koşulundaki kadınlar kendilerine sunulan olumsuz duyguların birçoğunu (DC için öfke ve aşağılanma; KC için küçümsenme) kontrol grubunda yer alan kadınlardan daha yoğun şekilde hissetmiştir. Duygular ve bilişsel süreçler arasında bağ kuran modelin varsayımlarından yola çıkarak cinsiyetçiliğin açığa çıkardığı duyguların kadınların testlerdeki performanslarını nasıl etkilediği incelendiğinde, sayısal performansla hiçbir duygunun ilişkili olmadığı ve sözel performansla ilişkili olan tek duygunun öfke duygusu olduğu görülmüştür. Cinsiyetçilikle karşılaşan kadınların deneyimledikleri öfke hissi arttıkça ortaya koydukları sözel performans da yükselmiştir.

İkinci deneyde öfke ve performans arasındaki ilişkiyi daha derinlemesine incelemek için yapılan analizler söz konusu değiş̧kenler arasındaki ilişkinin üç deney grubu 
arasından yalnızca DC koşulunda yer alan kadınlar için anlamlı düzeyde olduğunu ortaya koymuştur: DC'ye maruz kalan kadınların hissettikleri öfke duygusu arttıkça bu kadınların sergiledikleri sözel performans artmıştır. Cinsiyetçiliğe maruz kalma ve ortaya konan test performansı arasındaki ilişkinin ele alındığı analizler, DC ile karşılaşma ve sergilenen sözel performans arasındaki ilişkide kadınların deneyimledikleri öfke duygusunun anlamlı aracılık ettiğini ortaya koymuştur. Kısacası, Dardenne ve arkadaşlarının (2007) geliştirdiği deneysel düzeneğin uygulandığı ve bulguların Türkiye'deki geçerliliğinin test edildiği bu araştırmada -onların çalışmasından farklı olarak- kadınların performansını etkileyenin KC'ye değil, DC'ye maruz kalmak olduğu görülmüştür. Dardenne ve arkadaşlarının çalışmasında cinsiyetçiliğe maruz kalmanın neden performans düşüşüne yol açtı̆̆ını açıklamak için ortaya sürdükleri görüşlerden “istenmeyen düşünceler görüşü" destek bulmuşken, mevcut araştırmadan elde edilen sonuçlar üç yaklaşım arasından en fazla "öfke temelli tepki görüşü" ile uyumludur. DC ile karşı karşıya gelen kadınların öfke duygusunda deneyimlediği artışın, bu kadınların sözel testteki performanslarının yükselmesinde rol oynadığı bulgusuna Tepkisellik Teorisi perspektifinden bakıldığında, ortaya çıkan resim anlamlanmaktadır. KC koşulunda yer alan kadınlar her ne kadar maruz bırakıldıkları ifadelerin içindeki cinsiyetçiliği yakalayabilmiş olsalar da; DC ile KC'nin bu kadınların adalete ilişkin algılarını birbirinden farklı şekilde etkilemesi olasıdır. Açık bir dil üzerinden ifade edilen DC'yi adaletsizlik olarak değerlendirmek, KC'ye kıyasla daha hızlı ve kolay şekilde gerçekleşebilir. Dolayısıyla, DC ile karşılaşan kadınların adaletsizliğe tepki olarak öfke deneyimlemeleri ve bu adaletsizliği ortadan kaldırmak için daha çok çaba sarf etmeleri mümkündür. $\mathrm{Bu}$ etki yalnızca kadınların kendilerini başarılı gördükleri sözel alanda ortaya çıkmıştır. Sonuçlar, DC'ye maruz kalmanın ardından öfke hisseden kadınların, kendilerine pek güvenmedikleri bir alanda çaba sarf etmek yerine zaten iyi olduklarını düşündükleri bir alanda kendilerini ispatlamaya çalıştıklarını göstermesi açısından önemlidir.

Çalışmanın tartışılmaya değer asıl önemli sonucu, neden Dardanne ve arkadaşlarının (2007) çalı̧̧masında "istenmeyen düşünceler" görüşünü destekleyen bulgular elde edilirken, mevcut çalışmada "öfke temelli tepki” yaklaşımının beklentilerine uyacak şekilde sonuçlar elde edildiğidir. Araştırmalar arasında ortaya çıkan bu çelişkili bulguların çeşitli açıklamaları olabilir. İlk açıklama, mevcut araştırmada kadınların KC ifadelerini de DC ifadeleri kadar cinsiyetçi algılarken, Dardenne ve arkadaşlarının çalışmasında katılımcıların KC ifadelerini cinsiyetçi algılamamış olmaları olabilir. KC'deki örtük cinsiyetçiliği algılayabilmekle ilgili bu farklılıktan ötürü, mevcut çalışmada KC koşulunun katılımcılarının, cinsiyetçi deneyimler ile karşılaşmanın yarattığı rahatsızlığı cinsiyetçiliğin kaynağına atfetmeleri, Dardanne ve arkadaşlarının çalışmasında ise KC koşulunun katılımcıların aynı rahatsızlığı kendi benliklerine atfetmiş olmaları mümkündür. Mevcut çalışmada KC koşulundaki kadınların performansının kontrol grubundan farklılaşmamış olması, bu kadınların istenmeyen düşünceler ile ilgili bilişsel bir yük taşımamasından kaynaklanıyor olabilir.

İki araştırmada cinsiyetçiliğe maruz kalma ve bilişsel performans arasındaki ilişkinin neden böylesine farklı bulunduğuna getirilebilecek açıklamaların ikincisi, çalışmaların yürütüldüğü kültürler ile ilgilidir. Tehdit ve engellenmişlik durumunda farklı kültürlerden gelen kişilerin gösterdiği tepkisellik düzeyi birbirinden farklılaşmaktadır (Miron ve Brehm 2006). Literatürde, bireyci kültürlerde yaşayan kişilerin bireysel kimliklerine yönelen tehdit karşısında daha hassas oldukları; kolektivist kültürlerde 
yaşayan bireylerin ise sosyal kimliklerini hedef alan tehdit öğeleri karşısında daha duyarlı olduklarını gösteren bulgular mevcuttur (Örn. Jonas ve ark. 2009). Türkiye ve Belçika bu boyut üzerinden karşılaştırıldığında, Türkiye daha kolektivist, Belçika ise daha bireyci olarak değerlendirilir (Phalet ve Claeys 1993). Dolayısıyla, bu iki farklı kültürden gelen kadınların karşılaştıkları cinsiyetçilik deneyimine birbirinden farklı tepkiler göstermeleri şaşırtıcı değildir. Bireysel hedeflerden ziyade grubun hedeflerine öncelik veren Türkiye gibi kolektivist yapıdaki toplumlarda yaşayan kadınların grup kimliklerini tehdit eden cinsiyetçilik deneyimine, Belçika gibi bireyci kültürlerdeki kadınlara kıyasla daha duyarlı olmaları ve bu deneyim sonrasında daha yüksek düzeyde tepkisellik göstermeleri mümkündür. Mevcut araştırmanın sonuçlarının Dardenne ve arkadaşlarınınkinden farklılaşmasının bir başka sebebi ise daha teknik olabilir. Belki de, araştırmalarda bilişsel performans ölçümü için kullanılan testlerin birbirinden farklı olması, sonuçlardaki farklılığa yol açmıştır.

Dardanne ve arkadaşlarının çalışması ile mevcut çalışma, kadınların cinsiyetle özdeşleşme düzeylerine ilişkin bulguları açısından da farklılık göstermektedir. Dardanne ve arkadaşlarının araştırmasında DC, sadece kadın kimliği ile düşük düzeyde özdeşleşen katılımcıların bilişsel performansını olumsuz etkilemiştir. Araştırmacılar bu sonuçları, cinsiyetle özdeşleşme düzeyinin ayrımcılığın hedefi olan kadınlar için koruyucu bir işlevi olduğu şeklinde yorumlamıştır. Mevcut araştırmanın her iki deneyinden gelen bulgularda ise cinsiyetle özdeşleşme düzeyinin cinsiyetçiliğin ardından kadınların testlerde sergiledikleri performans ile ilişkili olmadığı görülmüştür. Öte yandan, ikinci deneyden gelen bulgular, cinsiyetle özdeşleşme düzeyinin farklı bir süreçte önemli bir etmen olabileceğine işaret etmiştir: Özdeşleşme düzeyi, kadınların ayrımcılık deneyimi ardından hangi duyguları hissedeceklerini etkileyen bir faktördür. Her bir deney koşulunda yer alan kadınların rapor ettikleri duygular ayrı ayrı incelendiğinde, kontrol grubundaki kadınlarda cinsiyetle özdeşleşme düzeyi yükseldikçe huzur, güven ve mutluluk gibi olumlu duyguların arttığı bulunmuştur. Bu bulgudan hareketle, cinsiyetle özdeşleşme düzeyi, cinsiyetçi ögeler içermeyen bağlamlarda, kadınların olumlu duygular deneyimlemesini kolaylaştıran bir faktör olduğu söylenebilir. KC'ye maruz kalan kadınlara bakıldığında ise, cinsiyetle özdeşleşme ve duygular arasında anlamlı bir ilişki olmadığı görülür. Özdeşleşme, kadınların olumlu duygular hissetmeleri ile ilgili olsa da korumacı tutumlar karşısında bu ilişki ortadan kalkmıştır. DC ile karşılaşan kadınlarda ise cinsiyetle özdeşleşme, olumsuz duygularla ilişkili bir değişken olarak ortaya çıkar. Ayrıntılı incelendiğinde, DC'nin ardından cinsiyetle özdeşleşme düzeyi yüksek olan kadınların yaşadığı huzursuzluk hissi azalırken, bu kadınların deneyimlediği aşağılanma hissinin arttığ1 anlaşılmıştır. Bu duyguların her ikisi de olumsuz olmakla beraber, duyguların kaynakları ve yol açtığı sonuçlar birbirinden farklılaşabilir. Dışsal kaynaklı bir his olan aşağılanma, genellikle çevreden birilerinin takındığı bir tutum ya da sergilediği bir davranı̧̧ sonucunda ortaya çıkar (Fernández ve ark. 2015). Fakat huzursuzluk hissinin daha içsel süreçlerle ilgili olabileceği ve bu his deneyimlendiğinde duygunun neye veya kime atfedileceğinin daha belirsiz olabileceği düşünülebilir. Dolayısıyla, kaynağı belirgin olmayan huzursuzluk hissinin daha engelleyici; nedeni kolay fark edilen aşağılanma hissinin ise daha motive edici olabileceğini beklemek mümkündür. Özdeşleşme düzeyi ve deneyimlenen duygular hakkında elde edilen tüm bu bulgular özetlendiğinde, özdeşleşme düzeyinin cinsiyetçiliğin ardından kadınların gösterdiği bilişsel performansla doğrudan ilişkili olmadığı; fakat performansa etki edebilecek bazı duyguların deneyimlenmesi ile bir ölçüde ilişkili olduğu söylenebilir. 
Mevcut araştırmanın tartı̧̧maya değer diğer bazı bulguları, cinsiyetçilik ile bilişsel performans arasındaki ilişkide bazı değişkenlerin düzenleyici ve aracı rolüne ilişkindir. Araştırma kapsamında yürütülen her iki çalışmada KC ve DC test performansları üzerindeki etkisinde, katılımcıların benlik saygısı ve cinsiyetle özdeşleşme düzeylerinin düzenleyici rolü incelenmiştir. Bulgular, ne benlik saygisı ne de cinsiyetle özdeşleşme düzeyinin bu süreçte düzenleyici bir etkisi olmadığına işaret etmiştir. Benlik saygısı ile ilgili beklentilerle tutarlı olmayan sonuçların deney düzeneğinden kaynaklı olabileceği düşünülmektedir. Katılımcıların, ilk kısmını işe alım provası olarak gördükleri bu araştırmada, daha olumlu bir başvuran görünümü çizebilmek adına ölçek maddelerini yanlı bir şekilde doldurması, beklenen etkinin ortaya çıkmasının önünde bir engel olabilir. Cinsiyetle özdeşleşme düzeyi ile ilgili analizlerde, cinsiyetçiliğe maruz kalma ve test performansı arasındaki ilişkiye özdeşleşme düzeyinin düzenleyici herhangi bir etkisi olmadığı ortaya çıkmış, öte yandan, kadınların cinsiyetçiliğin ardından deneyimlediği duygular üzerinde cinsiyetle özdeşleşmenin önemli bir rolü olduğu anlaşılmıştır. İkinci çalışmanın sonuçlarında görüldüğü üzere, kadınların karşılaştıkları cinsiyetçilik sonrasında hangi duyguları hissettiği cinsiyet grupları ile ne ölçüde özdeşleştiklerine bağlıdır.

KC ve DC'ye maruz kalmanın, kadınların BP düzeyleri üzerindeki etkilerine dair önceki çalışmalar, cinsiyetçiliğin etkilerini yalnızca tek bir bilişsel test üzerinden ele almış ve KC'ye maruz kalmanın, kadınların performansını azalttığına işaret etmiştir (Örn. Dardenne ve ark. 2007). Bu araştırmalarda göz önünde tutulmayan nokta, cinsiyetçiliğin tüm bilişsel becerileri aynı şekilde etkilemiyor olma ihtimalidir. Her iki deneyden elde edilen sonuçlarda tam da bu ihtimal gerçekleşmiş, katılımcıların yer aldığ1 deney grubunun BP üzerindeki etkisinin testin içeriğine bağlı olduğu anlaşılmıştır. Araştırma bulgularına göre, deney gruplarının sergilediği sayısal performans birbirinden anlamlı düzeyde farklılaşmazken, sözel testte gruplar arasında anlamlı ölçüde bir farklılık görülmüştür. Özetlemek gerekirse, mevcut çalışmadan elde edilen kritik sonuçlardan birisi, cinsiyetçiliğin performans üzerindeki etkisinin ne tür bir cinsiyetçiliğe maruz kalındığına göre değişmesi ve bu değişimin öfke temelli tepki yaklaşımını destekleyecek yönde olması, ikincisi ise söz konusu etkinin bilişsel testin içeriğine bağlı olmasıdır.

Düşmanca cinsiyetçi ifadelerin öfke duygusu aracılığıyla sözel performansı arttırdığını gösteren mevcut çalı̧madan üretilen bulguların, kadınların cinsiyetçiliğin olumsuz etkilerinden nasıl korunabileceğine ilişkin geliştirilebilecek düşünce ve davranışlar noktasında faydalı bilgiler sunduğu düşünülmektedir. Literatürde, cinsiyetçi tutum ve ifadelerin hedefi olmanın kadınların depresyon, kayg1 (Borgogna ve Aita 2020) ve öz yeterlilik (Jones ve ark. 2014) gibi süreçler üzerinden psikolojik iyi oluşlarını olumsuz etkilediği kolaylıkla görülmektedir. Buradan elde edilen bulgular ise cinsiyetçiliğin olumsuz etkilerinden korunmanın bir yolunun kadınların kendilerinden şüphe etmektense, cinsiyetçi tutum ve davranışı fark etmek ve ayrımcıllğın sorumluluğunu o davranışın sahibine yüklemek olabileceğini göstermesi açısından kıymetlidir. Ayrımcı tutumların farkına varmak bu tutumların olumsuz etkilerinden korunmak için yeterli olmasa da gereklidir.

Mevcut çalışmanın hem birinci hem de ikinci deneyinde bazı sınırlılıklar söz konusudur. İlk deneyin en önemli sınırlılıkları örneklem sayısının az olması ve verilerin yalnızca Sosyoloji Bölümünde eğitim alan katılımcılardan toplanmasıdır. İkinci deney ile birinci deneyde gözlenen sınırlılıklar giderilmeye çalışılmış, bu çalışmada farklı bölümlerde eğitim alan daha büyük örneklemden veri toplanmıştır. İkinci deneyde temsil 
edilebilirliği arttırmak adına farklı bölümlerden öğrencilere ulaşılsa da verilerin büyük çoğunluğu yine sözel bölümlerdeki öğrencilerden toplanmıştır. Sayısal ve sözel test performansının sonuç değişkeni olarak incelendiği bu çalışmada, verilerin farklı alanlarda eğitim alan öğrencilerden dengeli bir şekilde toplanmaması, araştırmanın önemli sınırlılıklarından biridir. İleride yapılacak çalışmalarda verilerin hem sayısal hem de sözel bölümlerde eğitim gören katılımcılardan dengeli bir şekilde toplanması faydalı olabilir.

\section{Sonuç}

Araştırmanın tüm bu sınırlılıkları ile birlikte alanyazına önemli katkılar sunacağı düşünülmektedir. KC ve DC ile ilgili Türkiye'de yapılan önceki çalışmaların çoğu ilişkisel çalışmalardır ve bu araştırmalarda genel olarak, ayrımcı tutumları benimsemiş olmanın hangi süreçlerle ilişkili olduğuna dair değerli bulgular elde edilmiştir (Örn. Sakallı-Uğurlu ve Glick, 2003, Sakallı-Uğurlu ve Ulu 2003). Bu çalı̧̧manın Türkiye bağlamındaki önceki araştırmalardan farkı, konunun deneysel bir araştırma deseni üzerinden incelenmesidir. Cinsiyetçiliğin kadınların sözel ve sayısal performansına etkilerinin ortaya konup hangi süreçlerin bu etkiyi yaratmış olabileceğine dair daha önce Avrupa örnekleminde sınanan görüşlerin Türkiye örnekleminde incelenmesinin ulusal alanyazına katkı sağladığı düşünülmektedir. Ayrıca, bu çalışmayı temel alınan araştırmalardan ayıran belirgin bir yön, cinsiyetçiliğin bilişsel performans üzerindeki etkilerinin iki farklı alanda incelenmesidir. Cinsiyetçiliğin kadınlar üzerindeki etkisinin performans alanına bağlı olduğu sonucunun her iki çalışmadan gelen bulgularda yinelenmesi önemlidir. Ayrıca, KC ve DC'nin bilişsel performans üzerindeki etkisinin incelendiği mevcut çalışmada duygular ve motivasyon düzeyi gibi farklı süreçler bir araya getirilerek durumun geniş bir perspektiften incelenmesi sağlanmıştır. Tüm bu özellikleriyle, çalışmanın alanda yapılacak araştırmalara önemli katkılar sunacağı düşünülmektedir.

\section{Kaynaklar}

Balkıs M, Duru E (2010) Akademik erteleme eğilimi, akademik başarı ilişkisinde genel ve performans benlik saygısının rolü. Pamukkale Üniversitesi Eğitim Fakültesi Dergisi, 27:159-170.

Barreto M, Ellemers N (2005) The burden of benevolent sexism: How it contributes to the maintenance of gender inequalities. Eur J Soc Psychol, 35:633-642.

Becker JC, Wright SC (2011) Yet another dark side of chivalry: Benevolent sexism undermines and hostile sexism motivates collective action for social change. J Pers Soc Psychol, 101:62-77.

Bodenhausen GV, Sheppard LA, Kramer GP (1994) Negative affect and social judgment: The differential impact of anger and sadness. Eur J Soc Psychol, 24:45-62.

Bohner G, Ahlborn K, Steiner R (2010) How sexy are sexist men? Women's perception of male response profiles in the Ambivalent Sexism Inventory. Sex Roles, 62:568-582.

Borgogna NC, Aita SL (2020) Are sexist beliefs related to mental health problems?. Soc Sci J, 1-15.

Bosson JK, Pinel EC, Vandello JA (2010) The emotional impact of ambivalent sexism: Forecasts versus real experiences. Sex Roles, 62:520-531.

Brannon L (2010) Gender: Psychological Perspectives, 6th ed. New York, Routledge.

Burgess KD (2013) The effect of hostile and benevolent sexism on women's cardiovascular reactivity to and recovery from a laboratory stressor (Master Thesis). Florida, University of South Florida.

Connelly K, Heesacker M (2012) Why is benevolent sexism appealing? Associations with system justification and life satisfaction. Psychol Women Q, 36:432-443. 
Corning AF (2002) Self-esteem as a moderator between perceived discrimination and psychological distress among women. J Couns Psychol, 49:117-126.

Dardenne B, Dumont M, Bollier T (2007) Insidious dangers of benevolent sexism: consequences for women's performance. J Pers Soc Psychol, 93:764-779.

Dumont M, Sarlet M, Dardenne B (2010) Be too kind to a woman, she'll feel incompetent: Benevolent sexism shifts self-construal and autobiographical memories toward incompetence. Sex Roles, 62:545-553.

Faul F, Erdfelder E, Lang A, Buchner A (2007) G*Power 3: A flexible statistical power analysis program for the social, behavioral, and biomedical sciences. Behav Res, 39:175-191.

Fernández S, Saguy T, Halperin E (2015) The paradox of humiliation: The acceptance of an unjust devaluation of the self. Pers Soc Psychol Bull, 41:976-988.

Frijda NH, Kuipers P, Ter Schure E (1989) Relations among emotion, appraisal, and emotional action readiness. J Pers Soc Psychol, 57:212-228.

Glick P, Fiske ST (1996) The ambivalent sexism inventory: Differentiating hostile and benevolent sexism. J Pers Soc Psychol, 70:491-512.

Glick P, Fiske ST, Mladinic A, Saiz JL, Abrams D, Masser B et al. (2000) Beyond prejudice as simple antipathy: Hostile and benevolent sexism across cultures. J Pers Soc Psychol, 79:763-775.

Günsoy C (2011) Linguistic gender bias as a result of uncertainty: The moderating roles of group identification and sociostructural variables (Yayınlanmamış Yüksek Lisans Tezi). İstanbul, Boğaziçi Üniversitesi.

Hamilton HR, DeHart T (2020) Cheers to equality! Both hostile and benevolent sexism predict increases in college women's alcohol consumption. Sex Roles, 83:675-684.

Hayes AF (2013) Introduction to Mediation, Moderation, and Conditional Process Analysis: A Regression-Based Approach. New York, Guilford Publications.

Heatherton TF, Polivy J (1991) Development and validation of a scale for measuring state self-esteem. J Pers Soc Psychol, 60:895910.

Jonas E, Graupmann V, Kayser DN, Zanna M, Traut-Mattausch E, Frey D (2009) Culture, self, and the emergence of reactance: Is there a "universal" freedom?. J Exp Soc Psychol, 45:1068-1080.

Jones K, Stewart K, King E, Morgan WB, Gilrane V, Hylton K (2014) Negative consequence of benevolent sexism on efficacy and performance. Gend Manag, 29:171-189.

Kilianski SE, Rudman LA (1998) Wanting it both ways: Do women approve of benevolent sexism? Sex Roles, 39:333-352.

Luhtanen R, Crocker J (1992) A collective self-esteem scale: Self-evaluation of one's social identity. Pers Soc Psychol Bull, 18:302318.

McCoy SK, Major B (2003) Group identification moderates emotional responses to perceived prejudice. Pers Soc Psychol Bull, 29:1005-1017.

Miron AM, Brehm JW (2006) Reactance theory-40 years later. Zeitschrift für Sozialpsychologie, 37:9-18.

Moradi B, Subich LM (2004) Examining the moderating role of self-esteem in the link between experiences of perceived sexist events and psychological distress. J Couns Psychol, 51:50-56.

Phalet K, Claeys W (1993) A comparative study of Turkish and Belgian youth. J Cross Cult Psychol, 24:319-343.

Rosenberg M (1965) Society and the Adolescent Self-Image. Princeton University Press.

Sakallı-Uğurlu N (2010) Ambivalent sexism, gender, and major as predictors of Turkish college students' attitudes toward women and men's atypical educational choices. Sex Roles, 62:427-437.

Sakallı-Uğurlu N, Glick P (2003) Ambivalent sexism and attitudes toward women who engage in premarital sex in Turkey. J Sex Res, 40:296-302.

Sakallı-Uğurlu N, Ulu S (2003) Evlilikte kadına yönelik şiddete ilişkin tutumlar: Çelişik duygulu cinsiyetçilik, yaş, eğitim ve gelir düzeyinin etkileri. Türk Psikoloji Yazıları, 6:53-65.

Schmader T (2002) Gender identification moderates stereotype threat effects on women's math performance. J Exp Soc Psychol, 38:194-201.

Schmader T, Johns M (2003) Converging evidence that stereotype threat reduces working memory capacity. J Pers Soc Psychol, 85:440-452. 
Schwarz N (1990) Situated cognition and the wisdom of feelings: Cognitive tuning. In The Wisdom in Feeling, (Eds LF Barrett, P Salovey):144-166. New York, Guilford Press.

Swim JK, Hyers LL, Cohen LL, Ferguson MJ (2001) Everyday sexism: Evidence for its incidence, nature, and psychological impact from three daily diary studies. J Soc Issues, 57:31-53.

Thacker RA (1992) A descriptive study of behavioral responses of sexual harassment targets: Implications for control theory. Empl Responsib Rights J, 5:155-171.

World Economic Forum (2018) The Global Gender Gap Report. https://www.weforum.org/reports/the-global-gender-gap-report2018 (Accessed 10.01.2021).

Yumşak Ş (2004) Görme ve ortopedik engelli ergenlerin özsaygı düzeyleri ile kendilerine yönelik toplumsal tutumları algılamalarının çeşitli değişkenler açısından incelenmesi (Yüksek lisans tezi). Ankara, Ankara Üniversitesi.

Zawadzki MJ, Danube CL, Shields SA (2012) How to talk about gender inequity in the workplace: Using WAGES as an experiential learning tool to reduce reactance and promote self-efficacy. Sex Roles, 67:605-616.

Yazarların Katkıları: Yazarlar çalışmaya önemli bir bilimsel katkı sağladıklarını ve makalenin hazırlanmasında veya gözden geçirilmesinde yardımcı olduklarını kabul etmişlerdir.

Danışman Değerlendirmesi: Dış bağımsız

Etik Onay: Araştırma için ODTÜ Uygulamalı Etik Araştırma Merkezi İnsan Araştırmaları Komitesinden onay alınmıştır. Tüm katılımcılar aydınlatılmış onam vermişlerdir.

Çıkar Çatışması: Yazarlar çıkar çatışması bildirmemiştir.

Finansal Destek: Yazarlar bu çalışma için finansal destek almadıklarını beyan etmişlerdir

Yazarın Notu: Bu makale ilk yazarın ikinci yazarın danışmanlığında yaptığı yüksek lisans tezinden üretilmiştir.

Bu makalenin içeriği, 5-7 Eylül 2016 tarihlerinde İzmir'de gerçekleştirilen 19. Ulusal Psikoloji Kongresi'nde poster bildiri olarak sunulmuştur.

Authors Contributions. Authors attest that they have made an important scientific contribution to the study and have assisted with the drafting or revising of the manuscript.

Peer-review: Externally peer-reviewed.

Ethical Approval: Ethical approval was obtained from the METU Applied Ethics Research Center Human Research Committee for the study. All participants gave informed consent.

Conflict of Interest: No conflict of interest was declared by the authors.

Financial Disclosure: The authors declared that this study has received no financial support.

Authors Note: This article was produced from the master thesis of the first author under the supervision of the second author. The content of this article was presented as a poster presentation at the 19th National Psychology Congress held in Izmir on 5-7 September 2016. 